\title{
DZIEJE FRANCISZKANÓW W POLSCE PROWINCJI ŚW. ANTONIEGO I BL. JAKUBA STRZEMIĘ
}

\author{
W S TĘ P
}

Wiek XIII wykształcił nowe formy życia zakonnego, na których szczególnie mocne piętno wycisnęła osobowość św. Franciszka z Asyżu. Ówczesne zasady życia zakonnego oparte na regulach św. Augustyna i św. Benedykta nie zaspokojały całkowicie potrzeb duchowych ludzi wierzących tamtego czasu.

Św. Franciszek uważany był za jedną $z$ ważniejszych postaci w historii Kościoła. Dante Alighieri w swoim dziele Boska komedia nazwał go „słońcem człowieczego rodu". Duża liczba ludzi pragnących go naśladować zmobilizowała św. Franciszka do utworzenia trzech struktur zakonnych: zakonu męskiego - franciszkanów, zakonu żeńskiego - klarysek oraz III zakonu dla osób świeckich, zwanego obecnie Franciszkańskim Zakonem Świeckich.

Zakon franciszkański przez swoją wszechstronną działalność stał się szeroko znany. Franciszkanie osiedlali się głównie w miastach. W czasie gdy Kościołowi zagrazały herezje ze strony waldensów i albigensów, byli mocnym wsparciem Stolicy Apostolskiej. Również w czasach najazdu tatarskiego. Duchowi synowie św. Franciszka pracujący wśród ludu dotkniętego prądami heretyckimi dbali o wykształcenie teologiczne. Podejmowali studia teologiczne na ówczesnych uniwersytetach, a wielu z nich osiagnęło naukową sławę, m.in.: św. Bonawentura, św. Antoni Padewski, Aleksander z Hales, Jan Duns Szkot, Roger Bacon. Należy zaznaczyć, że w II soborze liońskim w 1274 r. uczestniczyło 32 biskupów franciszkańskich, a w soborze wienneńskim 56 . Wielu powołanych zostało do godności kardynalskiej, niektórzy zostali papieżami.

\section{POCZATKI ZAKONU NA ZIEMJACH POLSKICH}

Jeszcze za życia założyciela, św. Franciszka z Asyżu, franciszkanie rozprzestrzenili się w wielu krajach Europy. Po kapitule w 1219 r. rozeszły się grupy franciszkanów na południe do muzułmanów, za Alpy do Niemiec, Francji, Czech. Do Polski franciszkanie przybyli z Niemiec. Ich przybycie do Polski łączy się z postacią Jana z Pian del Carpini. 
Byl on prowincjałem Niemiec w latach 1228-1230 i prawdopodobnie wówczas zetknął się ze Słowianami. W 1232 r. objął rządy prowincjała w Saksonii i wówczas wysłał braci do Polski ${ }^{1}$.

W latach 1232-1233 franciszkanie otworzyli swój dom we Wrocławiu. Cztery lata później przybyli do Krakowa, a w następnych latach byli już w Opolu (ok. 1238), Inowrocławiu (1238), Toruniu (1239) i Szczecinie $(1240)^{2}$. O swojej podróży i pobycie w Polsce Jan del Carpini wspomniał w opisie podróży do wielkiego chana Mongołów z 1245 r. W organizacji i życiu franciszkanów, podobnie jak i innych zakonów żebrzących, prowincja spełniała bardzo ważną rolę. Wyznaczała ramy życia dużej liczby zakonników. W prowincji otrzymywali oni podstawy swojej formacji, a następnie uczestniczyli czynnie w działalności zakonu. Od poczatku obowiązywała zasada przenoszenia braci z klasztoru do klasztoru, ale w obrębie własnej prowincji. Na kapitule w Pradze w lipcu 1238 r. Jan z Pian del Carpini, z upoważnienia generała zakonu br. Eliasza z Kortony, utworzył prowincję czesko-polską, którą kapituła generalna w Rzymie zatwierdziła w następnym roku'.

Już w 1239 r. w czasie kapituły generalnej wyraźnie ustalono zasady kapitul prowincjalnych, także wyboru i odwoływania ministrów prowincjalnych potwierdzonych przez ministra generalnego. Kapituła prowincjalna, złożona $\mathrm{z}$ wybranych delegatów wszystkich klasztorów prowincji, miała odbywać się co rok. Stanowiła najwyższą władzę prowincji, to ona wyznaczała gwardianów w każdym klasztorze. Minister prowincjonalny w imieniu kapituly wydawał decyzje i czuwał nad wprowadzaniem w życie uchwał kapitulnych. W zarządzaniu pomagali mu czterej definitorzy wybierani także przez kapitułę. Ważnym elementem organizacji prowincji były okręgi terytorialne, zwane kustodiami, z kustoszem na czele ${ }^{4}$.

Według Konstytucji Narbońskich Bonawentury z 1260 r. nominacja kustoszy oraz gwardianów należała do prowincjała i definitorów każdej kapituły prowincjalnej $^{5}$. W 1239 r. zostały ustalone w zakonie 32 prowincje $^{6}$. W niedługim czasie

'Jordan z Gi an o, Chronica, „Analecta Franciscana”, Quaracchi 1885, t. 1, s. 17; Źródłami informacji do dziejów franciszkanów w Polsce od ich przybycia do końca XVII w. są prace historyczne o. Kazimierza Biernackiego (1629-1725); K. R o s e n b a i g e r OFMConv, Biernacki Kazimierz, [w:] PSB 1935, t. 2, s. 81; Dziela Biernackiego, [w:] J. B a r OFMConv, Udzial Polski w literaturze franciszkańskieji, Warszawa $1961 \mathrm{nr}$ 156, 1570.

${ }^{2}$ B. Z i e n t a ra, Henryk Brodaty i jego czasy. Warszawa 1975, s. 298-299; J. M i tk ow sk i, Kazimierz ksiaże kujawski, [w:] PSB 1966-1967, t. 12, s. 276-277; L. L e m m e n s, $Z u$ den Anfängen der Franziskanerklöster im Ordenslande, „Mitteilungen des CoppernicusVereins für Wissenschaft und Kunst" 1913 nr 21, s. 2 n.; H. H o o g e w e g, Die Stifter und Klöster der Provinz Pommern, Stettin 1925, t. 2, s. 449 n: poczatki klasztor!n w Gryfị datuje Hongeweg na 1242 r., Strzałowa - 1254 r., Pyrzyc między 1261 a 1281 r., uzupełniają tę listę Gryfice (Greifenburg) przed 1289 r. i Drawsko (Dramburg) ok. 1350 r. (por. odpowiednie rozdziały w obu tomach pracy Hoogewega; t. 1 ukazał się w 1924 r. również w Szczecinie).

${ }^{3}$ K. K a n t a k, Franciszkanie polscy 1237-1517, Kraków 1937, t. 1, s. 19-20.

${ }^{4}$ K. K a n t a k, Franciszkanie..., t. 1, s. 157-159; S. B a r c i k OFMConv, Zakon franciszkański w Polsce do 1517 roku, [w:] 750 lat franciszkanów w Polsce. Materiaty z sympozjum odbytego w dniach 22-23.11.1986 r. w Eodzi-Eagiewnikach, red. C. Napiórkowski, Niepokalanów 1995, s. 77-78.

${ }^{5}$ Statuta generalia Ordinis [...] edita Narbonne an 1260, wyd. M. Bihl, AFrH 1941 nr 34, s. $294-295$.

${ }^{6}$ K. Ka n t a k, Franciszkanie..., t. 1, s. 20-21. 
dodatkowo 2 prowincje uzyskały prawną akceptację. Do końca XV wieku w zakonie istniały 34 prowincje.

Wyodrębniona z prowincji saskiej i ustanowiona pierwsza prowincja słowiańska - czesko-polska zwana też była polsko-czeską. Do prowincji tej należały domy czeskie i polskie, a także klasztory znajdujące się na terenie Łużyc, Śląska i Prus. Te ostatnie tworzyły:

- kustodię złotoryjską - z klasztorami w Złotoryi (przed 1243), Zgorzelcu (1243), Lwówku Śląskim (ok. 1248), Legnicy (ok. 1264), Krośnie Odrzańskim (1272), Lubaniu (ok. 1273) i Żaganiu (1284);

- kustodię wrocławską - z klasztorami we Wrocławiu (ok. 1234), Świdnicy (1249), Środzie Śląskiej (1253), Nysie (1257), Namysłowie (ok. 1284), Brzegu (przed 1285), Ziębicach (ok. 1284);

- kustodię pruską - z klasztorami m.in. w Toruniu (1239), Chełmnie (1282), Braniewie (1296) i Nowem (1282). W 1263 r. kapitula generalna przeniosła kustodię złotoryjską z prowincji czesko - polskiej do saskiej. To samo uczyniła kapituła w 1272 r. z kustodią wrocławską. Kustodia pruska została przyłączona do prowincji saskiej między 1258 a 1284 rokiem $^{8}$.

Prowincja czesko-polska w XIII w. liczyła siedem kustodii, z których trzy były polskie. Były to kustodie:

1) krakowska - z klasztorami: Kraków (1237), Zawichost (po 1242), Nowe Miasto Korczyn (1257), Stary Sącz (1280), Nowy Sącz (1287) i Radomsko (1286);

2) kujawska, zwana później gnieźnieńską - z klasztorami: Inowrocław (1238), Kalisz (1257), Gniezno (1259), Oboniki (1259), Śrem (1270), Pyzdry (1277) i Głogów na Dolnym Śląsku (przed 1257);

3) gómośląska - z klasztorami: Opole, Głogówek (1264), Bytom (1257) i Wodzisław (ok. 1257).

Uwzględniając klasztory z prowincji czesko-polskiej, należące do prowincji saskiej i dom w Przemyślu (1237), trzeba zauważyć, że na obszarze odpowiadającym dzisiejszemu terytorium Polski, na przełomie XIII i XIV w. było 40 klasztorów franciszkańskich oraz 6 klasztorów klarysek ${ }^{9}$.

Niniejsza tabela ukazuje ilość kustodii i klasztorów w prowincjach czeskopolskiej i śląskiej na przełomie XIII i XIV w.

\begin{tabular}{|c|c|c|c|c|}
\hline \multirow{2}{*}{ Rok } & \multicolumn{2}{|c|}{ Prowincja czesko-polska } & \multicolumn{2}{c|}{ Prowincja saska } \\
\cline { 2 - 5 } & Kustodie & Klasztory & Kustodie & Klasztory \\
\hline 1272 & 7 & brak danych & 12 & brak danych \\
\hline 1282 & 7 & 31 & 12 & 75 \\
\hline 1316 & 7 & 40 & 12 & 100 \\
\hline 1340 & 7 & 43 & 12 & 87 \\
\hline
\end{tabular}

Zródło: J. K ł o c zow s k i, Bracia Mniejsi w Polsce średniowiecznej, [w:] Zakony franciszkańskie w Polsce. Lublin 1983, t. 1, cz. 1, s. 35.

${ }^{7}$ J. K ł o c zow sk i, Bracia Mniejsi w Polsce średniowiecznej, Lublin 1982 t. 1, s. $15-$ $-20 ;$ K. K a n t a k, Franciszkanie..., t. 1, s. 19-20, 36-39.

${ }^{8}$ K. K a n ta k, Początki franciszkanów w Polsce, Gdańsk 1923, s. 10-15; T e n ż e, Die Entstehung der polnischen Konvente der Böhmisch-Polnischen Franziskaner-Provinz $1929 \mathrm{nr}$ 16 , s. $81-119$.

${ }^{9}$ J. Kloczowski, Zakony na ziemiach polskich w wiekach średnich, [w:] Kościót w Polsce. Sredniowiecze, Kraków 1968, t. 1, s. 464-468; A. Zw i e r c a n OFMConv, Nowe spojrzenie na poczatki franciszkanów w Polsce, „Nasza Przeszłość” $1985 \mathrm{nr} 63$, s. 5-51 
Wiek XIII to okres szczególnego rozwoju zakonu franciszkańskiego na ziemiach polskich. W drugiej połowie tego stulecia została ustalona terytorialna granica prowincji czesko-polskiej z prowincją saska ${ }^{10}$.

Szybkie powstawanie klasztorów franciszkanie zawdzięczali m.in. wspaniałomyślności książąt piastowskich. Wyróżniał się wśród nich Bolesław Wstydliwy, książę krakowski, którego matka - Grzymisława, siostra - bł. Salomea i żona św. Kinga odznaczały się zarówno świętością życia, jak i wielkim poparciem dla Zakonu Braci Mniejszych i Sióstr Klarysek ${ }^{11}$.

Duże znaczenie dla rozwoju zakonu miał fakt, że franciszkanie, znając rodzimy język ludności, służyli miejscowemu duchowieństwu znaczną pomoca duszpasterska. $\mathrm{Na}$ ziemiach polskich od początku istnienia państwa ugruntowało się chrześcijaństwo rzymskokatolickie, w sąsiednich krajach, zwłaszcza: na Rusi, Litwie i w Mołdawii, istniało chrześcijaństwo prawosławne, czy też jeszcze pogaństwo $^{12}$. Rzadko moźna było tam spotkać katolików - byli nimi tylko osiadli kupcy i rzemieślnicy. Parafie katolickie były nieliczne i brakowało biskupstwa ${ }^{13}$.

Aby pomóc katolikom i przyczynić się do nawrócenia prawosławnych, Stolica Apostolska powołała do życia „Towarzystwo pielgrzymujących dla Chrystusa wśród niewiernych", składające się z misjonarzy franciszkańskich i dominikańskich. Jego trosce powierzyła pracę w tych krajach (1345 r.). Przełożony Towarzystwa, zwany wikariuszem generalnym, mający wladzę prawie biskupia był zatwierdzany przez Stolicę Apostolską. Papieże bardzo cenili i popierali prace Towarzystwa obdarzajac je licznymi przywilejami, szczególnie Aleksander IV, Klemens V i Jan XXII (Bullarium franciscanum II, V). Praca misjonarska była połączona z licznymi niebezpieczeństwami i wielu jej członków oddało życie za szerzenie Ewangelii1 ${ }^{14}$. W XIV w. utworzono wikariat na Rusi.

${ }^{10}$ J. Kł o c z ow sk i, Zakony na ziemiach polskich, s. 466 napisał: „Najpóźniej w 1239 r. doszło do wyodrębnienia się z prowincji saskiej prowincji czesko-polskiej, która właśnie w 1239 r. odbyła kapitułę prowincjalną we Wrocławiu, pod przewodnictwem Czecha Tworzymira". Być może wziął pod uwagę zatwierdzenie tej prowincji na wzmiankowanej kapitule generalnej w Rzymie w 1239 r., która zrewidowała i zmniejszyła liczbę prowincji utworzonych przez br. Eliasza bez powołania kapituły generalnej.

$"$ B. Wło da r s k i, Salomea, [w:] Hagiografia Polska, Poznań 1972, t. 2, s. 300-309; Vita sanctae Salomae reginae Halicensis. Auctore Stanislao Franciscano, wyd. W. Kętrzyński, „Monumenta Poloniae Historica" 1884, s. 770-796; M. W i tk ow sk a OSU, Kinga - Kunegunda, [w:] Hagiografia Polska, Poznań 1971, t. 1, s. 757-772; W. Z ał u s k i, Żywot bt. Salomei królowej halickiej, zakonnicy św. Klary, Warszawa 1893, 1899. Z. B u d k ow a, Kunegunda, PSB 1971, t. 16, s. 186-189; H. W y c zaw s k i OFM, Jolenta Helena, [w:] Hagiografia Polska, 1971, t. 1, s. 624-629; O. Łas z c zyńs k a, Jolenda, PSB 1964-1965, t. 11, s. 264-20́5.

${ }^{12} \mathrm{~K}$. Chody n i e cki, Kościót prawostawny a Rzeczpospolita Polska. Zarys historyczny 1370-1632, Warszawa 1934; M. J a gu sz, Misje polskie na Litwie, [w:] Historia Kościota w Polsce, Poznań-Warszawa 1974, t. 1, cz. 2, s. 201, 299-301.

${ }^{13}$ Benedykt Polak, [w:] PSB 1935, t. 1, s. 424-425; W. A b r a h a m, Powstanie organizacji Kościola tacinskiego na Rusi, Lwów 1904, s. 89 93; K. Chod y n i ck i, Próby zaprowadzenia chrześcijaństwa na Litwie przed r. 1386, PH 1914 nr 18, s. 215-319.

${ }^{14} \mathrm{~K}$. Chodynicki, Legenda o męczeństwie czternastu franciszkanów w Wilnie, "Ateneum Wileńskie" 1927, s. 53-78; K. K a p i t a ń c z y k, Udzial Polaków w dziele misyjnym, Poznań 1933, (misje na Wschodzie nie zostały jeszcze całościowo opracowane). J. R i c h a rd, Les missions chez les Mongols aux XIIle et XIVe siècle, [w:] Histoire universelle des missions catholiques, red. S. Delacroix, Paris 1956, s. 173 n. 
Sytuacja poprawiła się znacznie po 1340 r., gdy król Kazimierz Wielki ponownie włączył Ruś i część Mołdawii w granice Rzeczpospolitej. Wówczas praca misjonarzy stała się łatwiejsza. Zaczęto budować kościoły katolickie, zakładać klasztory i kłaść podwaliny pod stolice biskupie w Haliczu, później we Lwowie, Łucku, Chełmie, Przemyślu, Kamieńcu Podolskim i Serecie. W drugiej połowie XIV w. w miastach tych były już stałe rezydencje biskupie, z biskupami wywodzącymi się przeważnie spośród franciszkanów i dominikanów ${ }^{15}$.

Zapotrzebowanie na misjonarzy ciagle rosło. Chcąc powiększyć ich liczbę, papież Urban V w specjalnym piśmie z 4 VIII 1370 upoważnił Mikołaja z Krosna, franciszkanina, który wiele lat pracował w Mołdawii, na Litwie i Rusi, do wybrania z różnych prowincji 25 zakonników, nawet bez zgody ich przełożonych, i wysłania ich do tych krajów dla umocnienia i rozszerzenia wiary katolickiej. Mikołaj z Krosna otrzymał taką władzę również od kolejnego papieża - Grzegorza XI. Największy rozkwit i znaczenie osiagną wikariat za czasów bł. Jakuba Strepy († 1409), najpierw wikariusza generalnego Towarzystwa, a później arcybiskupa w Haliczu i we Lwowie ${ }^{16}$.

Po ustanowieniu hierarchii kościelnej na Rusi istnienie Towarzystwa nie było konieczne, dlatego też zostało ono zniesione dekretem kapituły generalnej w Asyżu w 1430 r. Wszystkie domy franciszkańskie na Litwie i Rusi zostały wówczas przyłączone do prowincji czesko-polskiej ${ }^{17}$.

\section{PROWINCJA POLSKA}

Po przyłączeniu w $1430 \mathrm{r}$. do prowincji czesko-polskiej klasztorów Rusi: Lwów (ok. 1350), Halicz (1367), Sanok (1377), Krosno (przed 1397), Gródek Jagielloński (przed 1400), Kamieniec Podolski (przed 1400) oraz klasztorów Litwy: Wilno (1332), Pińsk (po 1396), Drohiczyn (1409) i Kowno (ok. 1409), stała się ona tak rozległa, że zarządzanie nią i przeprowadzanie wizytacji było bardzo trudne. Na ziemiach Polski średniowiecznej wraz z Pomorzem i Prusami oraz na ziemiach państwa polsko-litewskiego pod koniec XV w. było 69 klasztorów ${ }^{18}$. Zapewne dlatego za rządów prowincjała Walentego z Krosna (1513-1517) utworzona została $\mathrm{z}$ dawnej prowincji czesko-polskiej - prowincja polska z siedziba w Krakowie ${ }^{19}$. Tak więc Provincia Ordinis Minorum per Bohemiam et Poloniam

${ }^{15}$ A. F. Grabsk i, Polska w opiniach Europy zachodniej XIV-XV w., Warszawa 1968, s. 150 n.; J. K ło c zow sk i, Franciszek z Asyzu w Kościele i spoteczeństwie swoich czasów, „Ateneum Kaplańskie" 1977 nr 408, s. 24-38.

${ }^{16} \mathrm{Z}$. G o g o 1 a OFMConv, Blogostawiony Jakub Strzemie, franciszkanin, arcybiskup Halicko-Lwowski, „W nurcie franciszkańskim” $1997 \mathrm{nr} 6$, s. 143-151.

${ }^{17}$ Archiwum Generalne Braci Mniejszych Konwentualnych (AGBMConv): sygn. Pol. - S. Ant. e B. Giac. (dokumenty 3 dawnych prowincji historycznych w Polsce: polska, ruska, litewska); A. A b r a h a m, Powstanie organizacji Kościola lacińskiego na Rusi, Lwów 1904 t. 1, s. 12-14.

${ }^{18} \mathrm{~J}$. Kło c z ow s k i, Zakony w Polsce 960-1972, [w:] Metody $i$ źródla do badań z historii spolecznej XIX i XX w., Lublin 1975, s. 11

${ }^{19}$ Najstarszy wykaz konwentów franciszkańskich - „Provinciale Ordinis Fratrum Minorum Vetustissimum", oprac. C. Eubel, BulFr V (1898), s. 679-604. Tekst zachował się w dwóch kodeksach (Vaticano lat. nr 1960 i Bambergensi sign. E. III, 11 - według C. Eubela) opartych, jak sądzi wydawca, o jeden rękopis najprawdopodobniej z drugiej ćwierci XIV w. U schyłku XIV w. Bartomiej z Pizy (De confermitate vitae Beati Francisci ad vitam Domini Iesu, Af IV- 
dotrwała aż do $1517 \mathrm{r}^{20}$ Patronem nowej prowincji został św. Franciszek. Liczyła ona 32 klasztory i ok. 600 zakonników. Od tego czasu w granicach Królestwa Polskiego istniała jedna prowincja franciszkańska z konwentami: w Wielkopolsce, Małopolsce, na Rusi Białej i Czerwonej, na Podolu i Litwie. Taki stan trwał do 1622 r., tj. rządów o. Emiliana Cibo ${ }^{21}$.

Ruch obserwancki w Polsce w latach czterdziestych XV w. wywalczył sobie w łonie zakonu zupełne wyłączenie $z$ istniejących struktur prowincjalnych, a nawet niezależność od generalnych władz ${ }^{22}$. Przełom na tym polu dokonał się we Włoszech, gdzie ruch obserwancki był szczególnie silny. W sposób jednoznaczny ruch ten poparli: św. Bernardyn ze Sieny i św. Jan Kapistran. W celu zaprowadzenia pokoju w zakonie papież Marcin V zwołal kapitułę generalną w $1430 \mathrm{r}$. w Asyżu. Nakazał jednocześnie św. Janowi Kapistranowi zredagować nowe konstytucje, które potem zostały potwierdzone bulla. Konstytucje Marcinowe miały na celu przywrócić jedność. Zniosły funkcje wikariuszów, jakie otrzymali obserwanci, wprowadziły instytucję syndyków apostolskich, zniesioną przez papieża Jana XXII, znosiły posiadłości ziemskie i stałe dochody, przewidywały zniesienie stałych fundacji i zakazywały przyjmowania pieniędzy ${ }^{23}$.

Nowy generał Wilhelm z Casale (1430-1442) ślubował zachowywać nowe konstytucje, jednak wkrótce otrzymał zwolnienie z tego ślubu. Bulla z 23 VIII 1430 roku pozwalała zakonowi posiadać i administrować w zastępstwie i w imieniu Kościoła rzymskiego oraz przyjmować stałe źródła dochodu. W Polsce zaczęły także powstawać klasztory obserwanckie, które stały się mocnymi punktami oparcia dla misji Kapistrana ${ }^{24}$.

Początkiem historii polskiej gałęzi obserwantów franciszkańskich - bernardynów był pobyt Jana Kapistrana w Krakowie na przełomie lat 1453/1454. Zaproszony przez króla Kazimierza Jagiellończyka oraz biskupa Zbigniewa Oleśnickiego, przyczynił się on do założenia pierwszego domu bernardyńskiego koło Wawelu ${ }^{25}$.

-V [1906-1912]) daje następny wykaz prowincji, kustodii i konwentów, obejmując m.in. Ruś j Bośnię (t. 4, s. 503-569).

${ }^{20}$ Najbogatszym w treść dziełem o polskich franciszkanach jest K. Biernackiego Speculum Minorum wyd. w Krakowie w 1688 r. Autor miał uzyskać wiele źródeł, które bezpowrotnie przepadły w pożarze klasztoru krakowskiego w 1850 r. K. B i e r n a c k i, Speculum Minorum. Cracoviae 1688, s. 274-293; W. K a 1 in k a, Historia pożaru m. Krakowa. Kraków 1850, s. 91 n.; O bibliotece franciszkanów w Krakowie pisał A. G rabows ki, Historyczny opis m. Krakowa i jego okolic. Kraków 1822, s. 121.

${ }^{21}$ K. K a n ta k, Franciszkanie Polscy 15/7-1795, Kraków 1938, t. 2, s. 143, 175; AFK, sygn. E-I-3a i 4a. A. Karwacki, Materialy do historii Prowincji i konwentów oo. Franciszkanów na Rusi, t. 3, s. 53-54.

${ }^{22}$ Zakon Braci Mniejszych, założony przez św. Franciszka z Asyżı w 1209 r , a zatwierdzony przez papieża Honoriusza III w 1223 r., istniał przez 300 lat jako jeden zakon. W jego łonie niemal od początku dawały o sobie znać tendencje zmierzajace do ściślejszego zachowania reguły, zwłaszcza w kwestii ubóstwa. Te wewnętrzne prądy dały podstawy do wydania przez papieża Leona $\mathrm{X}$ bulli Ite et vos in vineam meam (1517 r.). tworzacej dwa odrębne zakony: Braci Mniejszych Konwentualnych i Braci Mniejszych Obserwantów. L e on X, Bulla, Ite et vos in vineam meam" z dn. $29 \mathrm{~V} 1517 \mathrm{r}$; L. W a d d in g, „Annales Ordinis Minorum”, 1517 nr 23 t. 16, s. 49-55.

${ }_{23}$ Tekst Chronologia Historico-Legalis seraphici Ordinis. Neapoli-Venetiis-Romae 1650-1795 t. 1, s. 90-99.

${ }^{24}$ K. K a n t a k, Franciszkanie..., t. 1, s. 331-333.

${ }^{25}$ K. K a n t a k, Bernardyni Polscy 1453-1572, Lwów, 1933 t. 1; H. E. W y czawski, Katalog Archiwum Prowincji OO. Bernardynów w Krakowie, ABMK 1961 nr 3, s. 25-102; 
Procesy reformy franciszkańskiej w Polsce đokonywały się na ogół w sposób pokojowy, ale można było zauważyć napięcia między poszczególnymi grupami i pewnego rodzaju współzawodnictwo ${ }^{26}$. W XV i XVI w. sympatia i hojność zamożniejszych fundatorów skierowała się w znacznej mierze ku nowej gałęzi franciszkańskiej - Braci Mniejszych Obserwantów (bernardynów) - rozszerzającej się wówczas w Polsce. Mimo to franciszkanie utworzyli w Polsce wiele nowych klasztorów, dlatego też zaistniała konieczność kolejnego podziału prowincji. W XVI w. kandydaci do zakonu rekrutowali się przeważnie spośród mieszczan. Choć pochodzenie łączylo ich z klasztorem krakowskim i nazywano ich synami konwentu krakowskiego, to powierzano im obowiązki w różnych klasztorach prowincji polskiej. Prowincjał w czasie wizytacji określał, do czego się nadaje poszczególny zakonnik ${ }^{27}$. W 1580 r. w klasztorze krakowskim wizytator apostolski Bonawentura Maresio utworzył studium na wzór włoskich gimnazjów zakonnych, którego celem było przygotowanie wykształconych spowiedników i kaznodziejów ${ }^{28}$. Rozległość prowincji, a także powody karności zakonnej, czego dowodem były postanowienia Kapituły generalnej w Rzymie z dn. 3 VI 1623 r. odnośnie Polski, były głównymi przyczynami rozdziału prowincji. Przed rozdziałem w całej Prowincji istnialo 46 klasztorów.

Powstałe w 1625 r. prowincje polska i rusko-litewska, mocą dekretu papieża Urbana VIII, przetrwały do 1686 r. Kapituła krakowska w 1626 r., po wyborze prowincjała Adriana Bratkowicza, uporządkowała organizacje prowincji polskiej, ustanawiając dwie kustodie: chełmińską i lubelską ${ }^{29}$. Patronem prowincji rusko-litewskiej obrano św. Antoniego Padewskiego, a jej minister Ghiza został mianowany w 1624 r. przez Kapitułę Generalną w Rzymie. W 1625 r. Albert Ghiza, jako prowincjał, otrzymał wyłączone z prowincji polskiej dwie kustodie: ruską i wileńska, które tworzyły nową prowincję ruską. Prowincja polska otrzymała archiwum, z zaznaczeniem, że ojcowie z kustodii ruskiej mieli do niego dostęp, natomiast konwentowi krakowskiemu nadano prawo do kwesty na Rusi ${ }^{30}$. Ghiza zwołał zebranie kapitularzy do Drohobycza w dniach 1-21 I 1626 r., które zajęło się organizacja prowincji. Obecnych było 18 gwardianów. Utworzono wówczas dwie kustodie: przemyską i kowieńska. W ten sposób dokonano podziału prowincji na cztery kustodie: lwowską i przemyską dla Rusi oraz wileńską i kowieńską

$1462 \mathrm{nr} 4$, s. 23-225, $1963 \mathrm{nr}$ 6, s. 17-65; Joan n is D fu g o s s i, Historia Polonicae. Liber XII. Opera Omnia XIV. Cracoviae 1878, s. 148-149. Surowszy kierunek, zwany na zachodzie Europy regularną obserwancja, został w Polsce wprowadzony przez św. Jana Kapistrana, kaznodzieję pokutnego, który w połowie XV w. przybył najpierw na krótko do Czech, by nawracać husytów, a następnie na Śląsk i do Polski południowej. Pierwsi bracia de observantia w Polsce nie dążyli do przejmowania klasztorów od konwentualnych i ich reformowania, jak to miało miejsce w krajach zachodnich. Tworzyli, zaczynając od dużych miast, swoje własne konwenty, zwane bernardyńskimi od pierwszych kościołów pod wezwaniem św. Bernardyna ze Sieny (fratres de monasterio s. Bernardini). Fundowane były one zwykle przez wyższe duchowieństwo i szlachtę.

${ }^{26}$ Archiwum Franciszkanów w Krakowie (AFK), Notiones praecipuae de conventibus scripsit Malegowski 1679, s. 13.

${ }^{27}$ AFK Quatuor Visitationes, s. 46-52, 107.

${ }^{28}$ AFK A. K a rwacki, t. 22, s. 19-22, 38.

${ }^{29}$ AFK Acta capitul. 1626 et $1658 ;$ K. K a n t a k, Franciszkanie polscy...t. 2, s. 143, 175

${ }^{30}$ O. B a r to s ze w i c z, Skargi na postępowanie Minorytów polskich na Litwie, [w:] AFK. Materiały do historii naszego Zakonu, s. 116-117. 
dla Litwy. Do kustodii lwowskiej przydzielono konwenty: Kamieniec, Krzemieniec, Lwów, Halicz, Międzyrzecz, Halicz św. Stanisław (rezydencja), Gródek, Korzec. Do kustodii przemyskiej przydzielono konwenty: Sanok, Szczebrzeszyn, Krosno, Biłgoraj, Zamość, Przemyśl. Do kustodii wileńskiej przydzielono konwenty: Olszany, Postawy, Pińsk, Wilno, Sienno. Do kustodii kowieńskiej przydzielono konwenty: Drohiczyn, Oszmiana, Kowno, Narwiliszki. Zebrani zaprotestowali przeciwko planom stanowiącym o przewadze polskiej prowincji ${ }^{31}$. Podjęte działania u generała odniosły pozytywny skutek i od tego czasu konwent krakowski nie zbieral już kwesty na Rusi. Ruś otrzymała konwent w Pińsku, który był jednym $z$ najbogatszych klasztorów ${ }^{32}$.

Nastapił szybki rozwój prowincji rusko-litewskiej, a nawet jej ekspansja poza granice kraju. W obrębie kustodii ruskich powstały nowe klasztory w Szumsku w 1656 r. i Jarosławiu w 1659 r. $^{33}$ Wojny kozackie znalazły jednak swój krwawy epilog w wojnie tureckiej przez utratę Kamieńca. Nawet w czasie względnego pokoju na kresach trwały ciagłe zamieszki. Najazd turecki i zabór Podola zniszczył wiele klasztorów ${ }^{34}$. Lepsza sytuacja była na Litwie, panował tam pokój i bezpiecznie mogły powstawać nowe klasztory. Zaznaczały się pewne odrębności Rusi i Litwy franciszkańskiej. Tak więc po 60 latach doszło do podziału i tej prowincji. $\mathrm{Z}$ pomysłem wydzielenia litewskiej prowincji wystapił o. Jakób Franciszek Dhuski, pochodzący z litewskiej szlachty. Życiorys miał bogaty i burzliwy. W $1681 \mathrm{r}$. został jednak biskupem bakowskim ${ }^{35}$. Utworzenie prowincji litewskiej zatwierdzila kapituła generalna w 1683 r., pozostawiając dalsze działania kapitule prowincjalnej, która odbyła się we Lwowie $1685 \mathrm{r}$. Z powodu podziału pojawiło się wiele problemów, pomimo to komisarz z Rzymu pozwolił na wybór tylko jednego prowincjała w osobie o. Antoniego Długosza, który sprzeciwiał się podziałowi, a nawet chciał go udaremnić, ale bez skutku. Patronem tej prowincji został św. Kazimierz. Prowincjałem nowej prowincji litewskiej został wybrany o. Marcjan Michałowski ${ }^{36}$.

Przez dwa ostatnie wieki niepodległości państwa polskiego (wiek XVII i XVIII) zakon franciszkański na ziemiach polskich znajdował się w pełni rozkwitu. W 1773 r. istniały już trzy prowincje:

prowincja polska pod wezwaniem św. Franciszka: 4 kustodie, 30 domów, 575 zakonników, w tym 385 kapłanów, 127 braci i 63 kleryków;

- prowincja ruska pod wezwaniem św. Antoniego: 4 kustodie, 29 domów, 257 zakonników, w tym 184 kapłanów, 52 braci i 21 kleryków;

- prowincja litewska pod wezwaniem św. Kazimierza: 4 kustodie, 31 domów, 422 zakonników, w tym 251 kapłanów, 101 braci i 70 kleryków. W sumie, franciszkanie pod koniec XVIII wieku mieli 12 kustodii, 90 domów, 1254 zakonników ${ }^{37}$.

${ }^{31}$ O. B a rtos zew ic z, Skargi..., s. 119-120.

32 AFK sygn. E-I-3a i 4 a A. Karwack i, Materiaty do historii Prowincji..., s. 56., s. $130-131$.

${ }^{33}$ Prowincjał $\mathrm{z}$ lat 1636-1639 Marek Korona sporządził opis konwentów prowincji i opublikowat w 1637 r. w Wilnie Speculum provinciae Russiae et MD Lituanie.

${ }^{34}$ K. Ka n t a k, Franciszkanie..., t. 2, s. 170-171.

${ }^{35}$ K. Ka n ta k, Franciszkanie..., t. 2, s. 174.

${ }^{36}$ AFK A. K a rw ack i OFMConv, Materialy dotyczace prowincji litewskiej $i$ konwentów litewskich t. 5, 19; AFK Inwentarz 124.

${ }^{37}$ [bidem. 
$\mathrm{Na} 18$ istniejących wówczas w Polsce diecezji franciszkanie mieli klasztory w 16 diecezjach, oprócz inflanckiej i smoleńskiej. Najwięcej konwentów było w diecezji wileńskiej 25 , a w łuckiej 11 , krakowskiej 9, lwowskiej 8 , wrocławskiej 9. Również kapłanów najwięcej pracowało w diecezji wileńskiej - 193, w krakowskiej 116, łuckiej 96, gnieźnieńskiej 91.

Do najliczniejszych klasztorów należały:

\begin{tabular}{|c|c|c|c|c|}
\hline Miasto & $\begin{array}{c}\text { Liczba } \\
\text { kaplanów }\end{array}$ & $\begin{array}{c}\text { Liczba } \\
\text { kleryków }\end{array}$ & $\begin{array}{c}\text { Liczba } \\
\text { braci zakonnych }\end{array}$ & Razem \\
\hline Kraków & 24 & 6 & 12 & 42 \\
\hline Lagiewniki & 19 & 4 & 6 & 29 \\
\hline Warszawa & 25 & 9 & 11 & 45 \\
\hline Lwów & 26 & 11 & 12 & 49 \\
\hline Zamość & 17 & 7 & 8 & 32 \\
\hline Wilno & 24 & 12 & 17 & 53 \\
\hline Pí́sk & 21 & 12 & 9 & 42 \\
\hline
\end{tabular}

Sląskie statystyki pochodzą z 1774 r. i przedłożył je na żądanie nuncjusza Garampiego biskup wrocławski Strachwitz. Klasztorów franciszkańskich wymienia ta statystyka 10: Bytom, Głogówek, Klodzko, Lwówek Śląski, Opole, Środa Sląska, Świdnica, Wodzisław, Wrocław (św. Doroty). Mieszkało w nich według jednej statystyki 211, a według drugiej 161 zakonników.

Razem ze Śląskiem było 99 klasztorów franciszkańskich i należało do nich 1465 zakonników. Najczęściej stosowane wezwania świątyń franciszkańskich to: Wniebowzięcia NMP - 17 kościołów, Św. Ojca Franciszka 11, Niepokalanego Poczęcia NMP 6, Św. Krzyża 6, Św. Stanisława 6, Św. Antoniego z Padwy $6^{38}$.

\section{LOSY POLSKICH PROWINCJI W OKRESIE ROZBIORÓW}

W wieku XVIII, a szczególnie w drugiej jego połowie dał się zaobserwować w Polsce kryzys powołań zakonnych ${ }^{39}$. Spadek powołań oraz antyzakonne działania zaborców wyrządziły wiele dotkliwych szkód w rozwijających się prowincjach franciszkańskich. Władze zaborcze zainteresowane były podporządkowaniem sobie Kościoła. Podjęto wysiłki zmierzające do zniesienia zakonów, a w najlepszym przypadku ograniczenia ich znaczenia i zakresu oddziaływania. Ponadto ówczesny antyklerykalizm i wolnomyślicielstwo propagowały tendencyjny pogląd, że zakony, z wyjątkiem tych, które zajmują się szpitalami i szkołami, są niepotrzebne oraz antyspoleczne ${ }^{40}$.

Rozbiory Polski, zapoczątkowane w 1772 r., wyrządzily wiele dotkliwych szkód w kwitnących prowincjach franciszkańskich. Kasaty klasztorów, jakie nastapiły po rozbiorach Polski, a także surowe ograniczenia życia zakonnego wpro-

${ }^{38}$ Franciszkanie na ziemiach polskich w 1772 r., ,WzP" nr 1(84), s. 24--26.

39 L. B i eńk owski, Oświecenie i katastrofa rozbiorów (II potowa XVIII w.), [w:] Chrześcijaństwo w Polsce. Zarys przenian 966-1979, red. J. Kloczowski, Lublin 1992, s. 319-340; S. A s k e n a y, Przedostatnie bezkrólewie. Fryderyk II i August III, [w:] Dwa stulecia XVIII $i$ XIX, t. 1, Warszawa 1901.

${ }^{40}$ S. Lit a k, Od Reformacji do Oświecenia. Kościót katolicki w Polsce nowożytnej, Lublin 1994, s. 110-124; J. K r a s z ew s k i, Polska w potowie XVIII wieku, Ateneum 1876. 
wadzone przez zaborców spowodowaly ogromne szkody i zmniejszenie się liczby zakonników. Pod obcymi, nieprzyjaznymi rządami łączność z generałem zakonu była prawie niemożliwa. Konwenty i zakonnicy poddani byli władzy biskupów (zniesiona egzempcja). Życie zakonne kierowane było dekretami cesarskimi. Kapituły zostały prawie zlikwidowane, władza prowincjałów ograniczona, przyjęcia do zakonów także ograniczone, a nowicjaty i seminaria systematycznie zamykane ${ }^{41}$.

Austria dokonała największych zaborów. Zajęła już w 1769 r. (tytułem restytucji) Spisz, potem w 1772 r. tereny na południe od linii brzegowej wzdłuż Wisły, od Śląska do ujścia Sanu, a stamtąd do Bugu w okolicy Dubienki i do Zbrucza ${ }^{42}$.

Rząd austriacki na zajętych terenach Polski ustanowił w 1785 r. tzw. prowincję galicyjską-wschodnią pod wezwaniem św. Antoniego, do której weszło 16 konwentów przeważnie z prowincji ruskiej. Nazwa łacińska brzmiała: Provincia Galiciae et Lodomeriae Ordinis Minorum Conventualium. W ten sposób między pierwszym a trzecim rozbiorem Polski istniały cztery prowincje polskich franciszkanów. Stan liczebny prowincji galicyjskiej w 1823 r. wynosił 58 franciszkanów, a w 1830 r. tylko 31 zakonników ${ }^{43}$.

Ingerująca we wszystko polityka rządu austriackiego dlawiła życie zakonne. Utrzymywanie jakiejkolwiek łączności zakonników w Galicji z ich przełożonymi w Rzymie było zabronione. Po dokonanych kasatach biskup mógł przyjąc do swojej diecezji (za wcześniej uzyskaną zgodą władzy politycznej) zakon istniejacy w granicach państwa austriackiego. Jeżeli zakon nie posiadał na terenie Austrii swoich klasztorów, to na założenie klasztoru zezwalał tylko minister, a zakon musiał zagwarantować utrzymanie klasztoru ${ }^{44}$. W myśl dekretu z $1847 \mathrm{r}$. uregulowano uposażenie klasztorów zakonów żebrzących, które wyznaczono z Funduszu Religijnego, dlatego przeprowadzanie kwesty było zabronione. Na kapłanazakonnika we Lwowie przyznawano 420 koron, na kleryka 315 koron, na brata zakonnego 290 koron $^{45}$.

Po trzecim rozbiorze Polski sytuacja ponownie uległa zmianie. W wyniku ustalenia granic między poszczególnymi zaborami kontakt niektórych domów czy nawet kustodii z prowincjałem okazał się niemożliwy. Stąd przez pewien czas istniała jeszcze jedna prowincja, tzw. pruska. Należały do niej domy dotychczasowej prowincji polskiej, które znalazły się pod zaborem pruskim, głównie z kustodii gnieźnieńskiej i chelmińskiej. W niedługim jednak czasie, tzn. do 1836 r., zlikwidowano zarówno tę prowincję jak i wszystkie jej domy. Podobny los spotkał franciszkanów polskich pod zaborem rosyjskim. Po Powstaniu Listopadowym, w 1832

${ }^{41}$ A. Chruszczewski, Zakony w XVII i XVIII w., „Znak" 1965 nr 17, s. 1591-1592; AFK sygn. E-I-3a i 4a A Karwack i, Moteriaty do historii Prowincii, s 119-120

${ }_{42}^{4}$ M. B o b z y c k i, Dzieje Polski w zarysie, Warszawa 1927, t. 2., s. 247-250.

${ }^{43}$ D. S y n o w i e c OFMConv, Franciszkanie polscy w latach 1889-1939, [w:] O. Maksymilian Kolbe. Srodowisko życia i dziatalności, red. J. R. Bar, Warszawa 1971, s. 36.

${ }^{44}$ J. B a r OFMConv, Polskie zakony, „Prawo kanoniczne” 1961 IV nr 1-4, s. 421-592; A. U r s e 1, Proces kleryków Seminarium tacińskiego we Lwowie 1836-1839, Lwów 1935; Szeroko opisuje sytuację w zaborze austriackim S. G ł ą b i ń s k i, Historia i statystyka monarchii austriacko-węgierskiej. Lwów 1904; W. C h o t k o w s k i, Historia polityczna Kościoła w Galicji za rzadów Marii Teresy, t. 2, Kraków 1909.

${ }^{45} \mathrm{~S}$. H o s zow k i, Ceny we Lwowie w latach 1701-1914, Lwów 1934; W. K a I in k a, Galicja i Kraków pod panowaniem austriackim, Kraków 1898; Konspiracje galicyjskie 183J-1845, Warszawa 1950. 
roku, zlikwidowano w prowincji ruskiej i litewskiej 41 konwentów, w których jeszcze w 1825 r. przebywało 203 ojców, 22 braci i 62 kleryków ${ }^{46}$.

W zmniejszonej zaś prowincji polskiej w $1864 \mathrm{r}$. rząd carski skasował niemal wszystkie konwenty (18), w których przebywało 73 ojców, 27 braci i 26 kleryków. Pozostał jedynie dom w Kaliszu jako tzw. etatowy, w którym zgromadzono starszych zakonników ${ }^{47}$.

Również rząd austriacki zlikwidował w $1784 \mathrm{r}$. większość domów prowincji galicyjskiej. Pozostało jedynie 7 domów: Św. Stanisław (koło Halicza), Horyniec, Lwów (z parafiami w Czyszkach i Hanaczowie), Kalwaria Pacławska, Krosno, Przemyśl i Sanok ${ }^{48}$.

\section{PROWINCJA GALICYJSKA}

Istniejąca pod zaborem austriackim miniaturowa prowincja galicyjska powiększyła się w 1866 r. na skutek przyłączenia do niej domu w Krakowie, który jako jedyny pozostał ze zlikwidowanej prowincji polskiej ${ }^{49}$.

Prowincja galicyjska składała się z dwu kustodii: lwowskiej i przemyskiej. Patronami jej byli: św. Antoni i bł. Jakub Strepa (Strzemię) $)^{50}$. W początkowych latach swego istnienia była ona nastawiona tylko na przetrwanie. Później jednak, gdy zaistniały nieco bardziej sprzyjające dla życia zakonnego warunki, przystapiono do wewnętrznej reformy. Reformę tę popierał generał zakonu o. Bonawentura Soldatich, a przeprowadzał ją ówczesny prowincjal o. Samuel Rajss, przy szczególnej pomocy swego długoletniego magistra młodzieży franciszkańskiej o. Remigiusza Dudy. Dzięki ich wysiłkom zostało 4 X 1888 r. wprowadzone w Krakowie życie wspólnotowe i przywrócono dyscyplinę zakonną. Rok później także w seminarium wprowadzono reformę. Popierali ją także następni prowincjałowie. Dzięki reformie prowincja galicyjska zaczęła się dynamicznie rozwijać. Wzrosła ilość powołań - liczba zakonników podniosła się z 57 (1883) do 83 (1892). Najpierw zwiększyła się liczba uczniów internatu - Małego Seminarium, któremu początek dał o. Innocenty Nycz, a który zreformował w 1906 r. o. Peregryn Haczela. W 1892 r. reaktywowano w Krakowie Franciszkańskie Studium FilozoficznoTeologiczne, z którego korzystali też klerycy innych zakonów. Z biegiem czasu odrestaurowano (wielkim nakładem kosztów) wszystkie klasztory i kościoły. Co więcej - założono w 1899 r. nowy klasztor, z murowanym kościołem, w Jaśle ${ }^{51}$.

${ }^{46}$ Cathalogus... Prov. Lithuaniae a. 1825.

${ }^{47}$ Elenchus... Prov. Poloniae in fine 1863 a.

${ }^{48}$ D. S y n o w i e c OFMConv, Franciszkanie polscy..., s. 36-38.

${ }^{49}$ D. S y n ow i e c OFMConv, P. Samuel Rajss observantiae religiosae in Provincia S. Antonii Patavii reformator (1850-1901), ,Miscellanea Francescana” 1977 nr 77, s. 136-137.

${ }^{50} \mathrm{~W} 1910$ r. przyjęto drugiego patrona prowincji bł. Jakuba Strepę.

${ }^{51}$ Archiwum Franciszkanów w Jaśle (AFJ) Księga akt konwentu oo. Franciszkanów w Jaśle w latach 1899-1945, s. 3, 9, 11; AFK A. K u b i t OFMConv, Utomki dzialalności polskich franciszkanów polskich w pierwszej polowie XX wieku, Kraków 1970, mps, s. 5; AFK Acta Provinciae Sancti Antonii Paduani Minorum Conventualium in Regno Galitiae ab a. 1879, s. $297,450-459$. 
W 1904 r. ośmiu młodych franciszkanów wyjechało do Stanów Zjednoczonych, przyczyniając się znacznie do powstania dwu polskich prowincji franciszkańskich w $\mathrm{USA}^{52}$.

Ponieważ corocznie wielka liczba robotników polskich (ok. 10 tys.) z Królestwa Polskiego, a przede wszystkim z Galicji udawała się na roboty do Danii, a nie mieli tam żadnej opieki duchowej, w 1907 r. wikariusz apostolski Danii i Islandii bp Jan von Euch zwrócił się do generała franciszkanów o. Dominika Reutera

z prośbą o przysłanie polskich franciszkanów do pracy w Danii w celu zaopiekowania się tymi robotnikami. Biskup ofiarowal franciszkanom kościół wybudowany w dużej mierze przez Polaków na Wyspie Lolland w miejscowości Maribo.

Powstanie dwóch następnych placówek duszpasterskich prowadzonych przez franciszkanów uwarunkowane zostało $\mathrm{z}$ jednej strony potrzebami religijnymi wiernych mieszkających w miejscowościach zbyt odległych od Maribo, z drugiej gorliwością apostolską Holendrów ${ }^{53}$.

Nakskov na wyspie Lolland przejęli franciszkanie jako odrębną parafię w 1913 r. Była to jednak parafia bez kościoła. Najpierw wybudowano kaplicę, a następnie, w większości $z$ ofiar Polaków, kościól pod wezwaniem św. Franciszka oraz dom dla 3 zakonników. Kościół został konsekrowany 6 listopada $1921 \mathrm{r}^{54}$

Trzecią parafię franciszkańską stanowiło Nykøbing na wyspie Falster. Również tamtejszy kościół pod wezwaniem Podwyższenia św. Krzyża powstał przede wszystkim dzięki ofiarności Polonii. Poświęcił go o. Cyryl Klessens 17 IX 1916 r. Przedtem odprawiano nabożeństwa $\mathrm{w}$ domu prywatnym. Kościół powiększono w 1927 r. Podobnie jak w Nakskov kościół w Nykøbing był zapisany dla wikariatu apostolskiego, wraz $\mathrm{z}$ wybudowanym przy nim domem i zakupionym dla franciszkanów ogrodem. W 1923 r. misję podniesiono do rangi kustodii, w ramach prowincji belgijskiej, jednak zlikwidowano ja w 1923 r. z powodu małej liczby zakonników ${ }^{55}$.

Nastapiło też znaczne ożywienie działalności duszpasterskiej w prowincji, czego wyrazem było m.in. przeprowadzenie koronacji dwu cudownych obrazów Matki Bozzej: w Kalwarii Pacławskiej (15 VIII 1882) i w Krakowie (20 IX 1908) ${ }^{56}$.

W 1907 r. udało się franciszkanom z Galicji osiedlić w klasztorze łagiewnickim, gdzie przebywali trzy lata. W 1911 r. musieli go opuścic ${ }^{57}$.

${ }^{52}$ D. S y n ow i e c OFMConv, Franciszkanie polscy 1772-1970, [w:] Zakony św. Franciszka w Polsce w latach 1772-1970, red. J. Bar, Warszawa 1978, s. 86-88.

${ }^{53}$ AFK: D. S y now ie c OFMConv, Reformy w Prowinnii Frolicyiskiej on Fronsiçknnów, Lublin 1962 (mps); C. K a m i ńsk i, Duszpasterstwo na Emigracji, [w:] Księga 1000-lecia katolicyzmu w Polsce, t. 1, Lublin 1969, s. 652; Stan i potrzeby badań nad zbiorowościami polonijnymi, red. H. Kubiak, A. Polch. Warszawa 1976, s. 244;

${ }^{54}$ AFK: A. Zwiercan OFMConv, Prace polskich franciszkanów wśród Polonii. Krosno 1974, mps.

${ }^{55}$ AFK: Teczka Dania, Korespondencja o. Rajnera Gościńskiego do prowincjała polskiego z 13.01.1932 r.; A. K a rw a c k i, Materiaty do historii Prowincji.., s. 459-460.

${ }^{56}$ S. B a r c i k OFMConv, Kalwaria Pactawska, Warszawa 1985, s. 107-108; AFK: Kronika klasztoru krakowskiego, s. 18.

${ }^{57}$ Katalog Franciszkańskiej Prowincji Matki Bożej Niepokalanej w Polsce, Warszawa 2000, s. 138 
Na początku XX w. liczba zakonników w prowincji nadal rosła. W $1908 \mathrm{r}$. było ich 111, a w roku 1912 - 130, w tym 69 kapłanów, 34 braci i 35 kleryków. Przed pierwszą wojną światowa prowincja obejmowala 11 placówek $^{58}$. Aby je obsłużyć, podana liczba zakonników była wystarczająca, była jednak za mała po uwzględnieniu ówczesnych potrzeb Polonii w Ameryce, penitencjarii we Włoszech oraz prac rekolekcyjnych i misyjnych w Galicji.

Pierwsza wojna światowa spowodowała wielkie spustoszenie w Europie i w naszym kraju, ale w jej wyniku doszło do odrodzenia państwa polskiego. To z kolei dało możliwość dalszego odradzania się prowincji m.in. przez ponowne objęcie domów dawnych prowincji franciszkańskich. W przededniu odrodzenia Polski zakon prowadzil normalną działalność tylko w Galicji. Dlatego też z nastaniem wolności wyruszyli franciszkanie do innych dzielnic Polski, aby odzyskać skasowane przez rządy zaborcze swoje domy. Prowincja nie zdołała jednak obsadzić wszystkich dawnych klasztorów. Wiele klasztorów, kościołów w byłych zaborach: pruskim i rosyjskim zostało zamienionych na świątynie parafialne, kierowane przez kapłanów diecezjalnych, same klasztory zajęte zostały w wielu wypadkach przez instytucje państwowe, a na wschodzie przez Cerkiew prawosławną. I tak w 1918 r. franciszkanie powrócili do: Radomska (27 V), Lagiewnik (8 VIII) i Kalisza (20 IX). W 1919 r. odzyskali klasztory w: Warszawie, Nieszawie, Wilnie i Grodnie (gdzie już od 1911 r. przebywał o. Melchior Fordon) ${ }^{59}$. Największe zasługi w odzyskiwaniu dawnych domów miał o. Alojzy Karwacki, prowincjał w latach $1918-1924^{60}$.

Po odzyskaniu niepodległości została restytuowana franciszkańska prowincja samorzutnie nazwana prowincją polska. Obejmowała ona domy należące poprzednio do prowincji galicyjskiej oraz odzyskane $\mathrm{z}$ dawnych prowincji: polskiej, ruskiej i litewskiej. Było ich w 1920 r. 16 i należały do 4 kustodii: lwowskiej, przemyskiej, krakowskiej i warszawskiej. Prowincja liczyła: 76 kapłanów, 26 braci, 12 kleryków, 10 kleryków-nowicjuszy i 28 kandydatów na braci. Patronami prowincji pozostali: św. Antoni Padewski i bł. Jakub Strepa (Strzemię) ${ }^{61}$.

W 1921 r. odzyskano klasztor w Poznaniu. Sześć lat później, w 1927 r., św. Maksymilian Kolbe założył Niepokalanów, w którym w 1929 r. zorganizował Małe Seminarium Misyjne.

W 1928 r. odzyskano klasztor w Gnieźnie. A dwa lata później, w 1930 r., św. Maksymilian założył Niepokalanów w Japonii. W tym samym roku odstapiono na potrzeby diecezji klasztor w Nieszawie oraz zamknięto Małe Seminarium we Lwowie. W następnym roku (1931 r.) prowincja polska przyjęła ponownie placówkę w Danii. Szczególnie wzrastał w liczbę braci Niepokalanów Polski. Dzięki działalności św. Maksymiliana i pozytywnemu oddziaływaniu społecznemu „Ry-

${ }^{58}$ Schematismus OFMConv Prov. S. Antonii de Padua et B. Jacobi de Strepa a. 1912; D S y n ow i e c, Franciszkanie, s. 36-37, 49, 62; te n ż e, P. Samuel, s. 147-148.

${ }^{59}$ O. Melchior Fordon (1862-1927). Jako kaplan diecezji wileńskiej w 1910 roku wstapił do franciszkanów; AFK: o. Witold G r a l, Franciszkanie zmarli w XX wieku, mps, t. 3, s. 24-25. A. W o j t c z a k OFMConv, O. Melchior Fordon, mps, Biblioteka franciszkanów w Krakowie. s. $189-190$.

${ }^{60}$ O. Alojzy Karwacki (1866-1924). AFK sygn. E-I-20, Stawniejsi franciszkanie...,

${ }^{61}$ AFK Acta coadunatae Provinciae Poloniae, Russiae, Lithuaniae S. Antonii et B. Jacobi de Strepa (A coadun. Prov. Pol.), s. 18-19, 57-61. 
cerza Niepokalanej" ponownie wzrosła ilość powołań ${ }^{62}$. W 1933 r. prowincja liczyła: 19 domów i 696 zakonników. W tej liczbie było: 84 kapłanów, 291 braci, 132 kleryków, 136 małoseminarzystów i 53 kandydatów na braci ${ }^{63}$. W tym też ro$\mathrm{ku}$ na kapitule prowincjalnej zaproponowano podzial na dwie prowincje, lecz nie zrealizowano go od razu, tylko 6 lat później. W międzyczasie powiększała się nadal liczba domów i zakonników. W 1934 r. podniesiono do rangi samodzielnych klasztorów domy w Hanaczowie i Czyszkach. W tym samym roku przyjęto jeszcze jedną placówkę duszpasterska, w Lubomierzu, i erygowano tam klasztor. W 1935 r. prowincja liczyła 411 braci zakonnych. Liczba działajacych kapłanów ciagle rosła, a pracujących w klasztorach braci było cztery razy więcej niż kapłanów. W 1935 r. rozpoczęto budowę domu w Gdyni, zaś rok później przyjęto plac pod budowę klasztoru w Skarżysku-Kamiennej. Planowano budować klasztor w Kozielnikach koło Lwowa i przyjęto rektorstwo kościoła w Morszynie Zdroju. W 1937 r. odzyskano klasztor w Radziejowie i ponownie w Nieszawie oraz w Kosowie. W 1938 r. przyjęto parafię w Zaczepicach oraz odzyskano klasztory w Iwieńcu i Dziśnie (wszystkie w archidiecezji wileńskiej).

Liczba domów wzrosła w dwudziestoleciu międzywojennym o 24 i wynosiła w 1939 roku 32, zaś liczba zakonników wzrosła do 1190, w tym: 141 kapłanów, 657 braci, 137 kleryków, 88 kandydatów na braci i 167 małoseminarzystów. Liczba zakonników zbliżyła się więc do stanu z okresu przedrozbiorowego ${ }^{64}$.

Zasadnicze normy prawne, na których opierała się organizacja i działalność zakonu, znajdowały się w konstytucjach zakonnych. W 1932 r. doszło do zmiany Konstytucji Urbańskich zatwierdzonych w 1628 r. przez papieża Urbana VIII $^{65}$.

Pod względem liczby zakonników franciszkanie zajmowali w Polsce drugie miejsce, pierwsze - jezuici. O ile liczebny rozwój franciszkanów w dwudziestoleciu międzywojennym był znaczny, o tyle poziom intelektualny i zakres działalności wzrastały powoli. Aby przyspieszyć przyjmowanie kandydatów na kleryków, otwarto Małe Seminarium, ale kwalifikacje kadry nauczycielskiej pozostawiały wiele do życzenia. Przyjmowano kandydatów do nowicjatu bez obowiązku matury, a klasy brakujące uzupełniano po nowicjacie. Prowincja nie rozwijała działalności naukowej, jak to czynili jezuici czy dominikanie. Na skutek zamieszek, jakie przeżyło życie zakonne w XVIII i XIX w., zaczęły funkcjonować praktyki przeciwne normom życia zakonnego, stąd pojawił się silny ruch zmierzający do odnowy życia zakonnego, który polegał na wprowadzeniu życia doskonale wspólnego. W maju 1882 r. definitorium generalne w Rzymie podjęło uchwałę odnośnie do przeprowadzenia reform. Generał zakonu o. Bonawentura Soldatich otrzymał upoważnienie od Kongregacji Biskupów i Zakonników do przeprowadzenia reform $w$ całym zakonie ${ }^{66}$. W polskiej prowincji dzieła reformy podjął się wybrany na prowincjała w 1879 r. o. Innocenty $\mathrm{Nycz}^{\varsigma}$, a późnıe jego następca o. Samuel

${ }^{62}$ L. D y c z e w sk j OFMConv, Niepokalanów - dzieto świętego Maksymiliana Kolbego, „Chrześcijanin w świecie” 1982 nr 109, s. 12-37.

${ }^{63}$ Schematismus Fratrum Minorum Conventualium in Polonia 1933, s. 80; D. S y no w i e c, Franciszkanie..., s. 40, 42-44.

${ }^{64}$ AFK: Acta Provinciae Poloniae... ab anno 1931, s. 127, 128, 131, 143, 150, 175 n., 193 n., 207, 232, 249.

${ }^{65}$ Constitutiones Urbanae..., In cap. IV Reg. tit. VI, nr 1, 4.

${ }^{66}$ Dekret Kongregacji Biskupów i Zakonników z dnia 27 II $1883 \mathrm{r}$.

${ }^{67}$ AFK sygn. E-I-20 A. K a r w a c k i, Stawniejsi franciszkanie w Polsce, mps, s. 130-132. 
Rajss $^{68}$. Reforma zakonu polskich franciszkanów rozpoczęta pod koniec XIX w. przebiegała powoli. Trudności wynikały z tkwiącego w starym pokoleniu zakonników przyzwyczajenia do wygód (życie partykularne) i niestarannej rekrutacji nowicjuszów. Kolejnym powodem była konieczność utrzymywania niewystarczająco obsadzonych placówek, w których trudno było o zachowanie pełnej dyscypliny zakonnej. Były jednak w tym okresie również przykłady dużego postępu i zaangażowania dzięki działalności wybitnych osobistości wśród franciszkanów polskich, m.in. o. Maksymiliana Kolbego, o. Wenantego Katarzyńca czy o. Józefa Melchiora Fordona. Okres od 1865 do 1939 roku w dziejach franciszkanów polskich zaznaczył się odrodzeniem karności zakonnej i rozwojem liczebnym zakonu.

\section{PONOWNY PODZIA $九$ NA DWIE PROWINCJE}

Propozycja podziału prowincji bujnie rozwijającej się wysunięta została w 1933 r. i zyskiwała coraz więcej zwolenników, miała także wielu nieprzychylnych, szczególnie ze strony starszych zakonników. Uważali oni, że lepiej będzie gdy zostanie jedna, choć dużą prowincją. Kapituła prowincjalna w 1936 r. poleciła przygotować podział na rok 1939. Dnia $30 \mathrm{~V} 1939$ r. rada prowincji przegłosowała projekt podziału na dwie prowincje: małopolską i wielkopolsko-mazowiecka. Każda z prowincji miała składać się z 15 domów. Szesnastym domem prowincji wielkopolsko-mazowieckiej miał być Niepokalanów japoński.

Domy prowincji małopolskiej znajdowały się na terenie archidiecezji krakowskiej i lwowskiej, a domy prowincji wielkopolsko-mazowieckiej na terenie archidiecezji warszawskiej, gnieźnieńsko-poznańskiej i wileńskiej ${ }^{69}$.

W kwestii przynależności poszczególnych zakonników do prowincji przyjęto dwie zasady:

1. Zakonnicy starsi oraz ci, którzy złożyli śluby sympliczne do 31 grudnia 1920 roku, mieli prawo wyboru przynależności do prowincji;

2. Młodsi należeli do prowincji, na terenie której urodzili się. Mogli jednak prosić o przynależność do drugiej prowincji.

Po uwzględnieniu wszystkich próśb ustalono, że do prowincji małopolskiej należy 81 ojców i 49 braci po ślubach wieczystych, a do prowincji wielkopolskomazowieckiej 66 ojców i 48 braci po ślubach solemnych. Pozwolenie na podział wydała Kongregacja do Spraw Zakonnych 24 lipca 1939 r. Samego podziału dokonano urzędowo na kapitule prowincjalnej odprawionej w dniach 23-25 sierpnia 1939 r. w Krakowie. Wybrano prowincjałów: o. Wincentego Borunia dla prowincji małopolskiej i o. Maurycego Madzurka dla prowincji wielkopolsko-mazowieckiej. Patronami prowincji małopolskiej pozostali nadal św. Antoni Padewski i bł. Jakub Strepa (Strzemię), a patronką prowincji wielkopolsko-mazowieckiej Matka Boża Niepokalana ${ }^{70}$.

Wybuch drugiej wojny światowej przeszkodził w dokładnym przeprowadzeniu programu podziału prowincji i doprowadził do nowego tymczasowego po-

${ }^{68}$ AFK sygn. E-I-20 A. K a rw a c k i, Stawniejsi franciszkanie w Polsce, mps, s. 154-158.

${ }^{69}$ AFK: Acta Provinciae Poloniae... ab anno 1931, s. 127 n.

${ }^{70}$ Acta Provinciae.., s. 260 n., 266-268; Katalog Prowincji Matki Bozej Niepokalanej, Warszawa 2000 , s. $59-65$. 
działu. Z powodu zajęcia przez Niemców obszarów centralnej i zachodniej Polski, a przez wojska radzieckie wschodnich obszarów podział Polski przebiegał z pólnocy na południe. Ponieważ granica prowincji przebiegała ze wschodu na zachód, przyczyniło się to do podziału każdej prowincji franciszkańskiej na dwie części. Pod władzą niemiecką znalazły się części zachodnie obu prowincji, pod władzą radziecką obie ich części wschodnie. W części prowincji Matki Bożej Niepokalanej, znajdującej się pod okupacją niemiecką, sprawował władzę prowincjał o. Maurycy Madzurek. Nie miał on jednak kontaktu $z$ konwentami wschodniej części swojej prowincji ${ }^{71}$.

Prowincja św. Antoniego i bł. Jakuba Strepy.w momencie zajęcia Polski przez okupantów praktycznie była bez władzy, gdyż ówczesny prowincjał 11 września 1939 r. udał się ze Lwowa (przez Rumunię) do Rzymu i tam już pozostał. Ojciec generał Beda Hess dnia 14 grudnia 1939 r. mianował o. Maurycego Madzurka - komisarzem generalnym części prowincji pozostającej pod okupacja niemiecką z komisariatem generalnym w Krakowie. Natomiast delegatem komisarza generalnego został o. Anzelm Kubit, którego już 11 marca 1940 roku o. generał B. Hess mianował komisarzem generalnym części prowincji pozostającej pod okupacją niemiecką. Część prowincji pozostającej pod okupacją radziecką wraz z częścią prowincji Matki Bożej Niepokalanej objął o. Albert Wojtczak, przebywający we Lwowie. O. Albert pełnił ten urząd przez trzy lata; zrezygnował z funkcji 29 grudnia $1942 \mathrm{r}^{72} \mathrm{Na}$ jego miejsce o. generał Hess mianował o. Kornelego Czupryka, który rozpoczął swą posługę - komisarza generalnego od 1 lutego $1943 \mathrm{r}^{73}$

Konwenty wschodniej prowincji Matki Bożej Niepokalanej po wybuchu wojny niemiecko-radzieckiej jeszcze przez pół roku podlegały komisarzowi lwowskiemu. Następnie ówezesny general, o. Hess, pismem z dnia 22 grudnia 1941 r., przekazał je pod władzę prowincjała warszawskiego ${ }^{74}$.

Do zmniejszonego komisariatu lwowskiego należały w tym czasie klasztory: Lwów, Halicz, Kozielniki, Czyszki, Hanaczów, Horyniec, Kalwaria Pacławska, Kosów z filią w Żabiem, Morszyn i Przemyśl. Poza tym franciszkanie prowadzili parafie: Robotycze, Boremel, Lewacze (obie w diecezji łuckiej) i Śniatyń, później zamiast Sniatynia parafię w Pistyniu. Komisariat ten podjął trud prowadzenia studiów filozoficzno-teologicznych dla grupy kleryków, którzy po wybuchu drugiej wojny światowej znaleźli się we Lwowie. Siedemnastu z nich otrzymało we Lwowie święcenia kapłańskie ${ }^{75}$. Wielką stratą dla komisariatu była likwidacja klasztoru w Haliczu. Nastapiło to 17 czerwca 1942 roku. Gestapo, przy pomocy ukraińskiej policji, aresztowało, a następnie rozstrzelało bardzo zasłużonego dla prowincji i zakonu o. gwardiana Peregryna Haczelę oraz o. Remigiusza Wójcika 1 br. Stefana Kosiorka. Na początku 1944 r. komisariat lwowski liczył 75 zakonni-

${ }^{71} \mathrm{~S}$. B a rc i k OFMConv, Franciszkanie na Dolnym Ślasku po II wojnie światowej 1945-1990, „W nurcie franciszkańskim” $1995 \mathrm{nr} 4$, s. 148-174; E. Ko o o dz i e j OFMConv, Studium franciszkańskie we Lwowie 1938-1944, „W nurcie franciszkańskim” $1995 \mathrm{nr} 4$, s. 130-145.

${ }^{72}$ AFK sygn. C II teczka Wojtczak Jan Albert 1907-1962. Nominacja, Rzym 11 III 1940.

${ }^{73}$ AFK sygn C II teczka Czupryk Tomasz Korneli 1904-1988. Życiorys.

${ }^{74}$ Acta Provinciae Poloniae sub tutela S. Antonii Pat. et B. Jacobi de Strepa ab anno 1931, AFK sygn. B-IVa-5, s. 361, 362, 364, 365, 366, 371, 382, 384, 432, 433, 436.

${ }^{75}$ E. Ko o o d z i e j OFMConv, Studium franciszkańskie we Lwowie 1938-1944, „W nurcie franciszkańskim" $1995 \mathrm{nr}$ 4, s. 155-169. 
ków: 50 ojców, 17 braci i 8 kleryków. Ten stan personalny utrzymał się do końca drugiej wojny światowej ${ }^{76}$.

Komisariat krakowski przez całą wojnę znajdował się pod okupacją niemiecką. Należały do niego klasztory w Krakowie, Radomsku, Jaśle, Krośnie, Sanoku i Lubomierzu. Ten ostatni klasztor został 4 grudnia 1943 r. spalony przez Niemców, a dwaj ojcowie i jeden brat wywiezieni do obozu ${ }^{77}$. W komisariacie tym znajdowało się seminarium; prowadziło ono działalność w Krakowie i częściowo w Radomsku. Terror okupacyjny panujący w kraju nie ominął też franciszkanów komisariatu krakowskiego. Kilku z nich zostało wywiezionych do obozów koncentracyjnych i podobnie jak o. Maksymilian Kolbe z Niepokalanowa, nie przeżyło wojny. Byli to m.in. o. Bonawentura Podhorodecki, były sekretarz prowincji, ówczesny rektor i wykładowca seminarium krakowskiego, bł. Antonin Bajewski, o. Euzebiusz Pelc, br. Rafał Skoczylas, br. Maciej Gruszka, o. Henryk Jamróg, br. Florian Masłowski ${ }^{78}$.

Do niedawna w Polsce można było mówić i pisać o tych, którzy doznali krzywdy z rąk okupantów niemieckich. Nie wspominano o ofiarach okupanta radzieckiego, zwłaszcza o zmarłych w radzieckich łagrach $\mathrm{i}$ więzieniach oraz w wyniku zsyłek. Obecnie istnieje wiele tablic upamiętniających ich śmierć, kilka $\mathrm{z}$ nich znajduje się w różnych klasztorach, m.in. na krużgankach przy Bazylice OO. Franciszkanów w Krakowie. Liczba wszystkich współbraci działających wówczas w Polsce $z$ dwóch prowincji OO. Franciszkanów (Zakonu Braci Mniejszych Konwentualnych), których dotknęła druga wojna światowa, jest duża:

16 zamęczonych w obozach koncentracyjnych;

32 rozstrzelanych i zabitych;

15 poległych w czasie działań wojennych;

4 zmarłych podczas tułaczki na obczyźnie.

Razem 67 osób, które straciły życie. W grupie tej znajduje się także jeden kapłan należący do prowincji św. Antoniego w USA ${ }^{79}$.

Istniała grupa franciszkanów, którzy znaleźli się i przebywali dłużej lub krócej w obozach i więzieniach niemieckich, a którym udało się przeżyć i doczekać wolności. Było ich 39. Osobną grupę stanowili franciszkanie, którzy zostali aresztowani w dniu 19 września 1939 r. w Niepokalanowie razem z o. Maksymilianem (pierwsze aresztowanie) i wraz z nim przebywali kolejno w obozach: Lamsdorf (Łambinowice) na Opolszczyźnie, Amtitz (Gębice) koło Gubina i w Ostrzeszowie na pograniczu Wielkopolski i Śląska. Wszyscy z tej grupy po prawie trzech miesiącach, w dniu 8 grudnia 1939 roku - w uroczystość Niepokalanego Poczęcia NMP, zostali zwolnieni i powrócili do Niepokalanowa lub innych klasztorów. Niektórzy z nich, podobnie jak o. Maksymilian, zostali później powtórnie aresztowani i zginęli. Dwul-

${ }^{76}$ Acta Provinciae... ab anno 1931, AFK sygn. B-IVa-5, s. 415, 417-419, 429, 431-436.

77 Z. Gogola OFMConv, Dzieje miejscowości i parafii Lubomierz. Kraków 1998, s. $230-231$.

${ }^{78}$ AFK sygn. E-I-20. A. Karwacki, Stawniejsi franciszkanie..., s. 149, 198; Księga zmartych oo. Franciszkanów w Polsce od roku 1950, Oprac. J. Bar, Kraków 1986 mps, s. 269, 340.

${ }^{79} \mathrm{M}$. H a ł a m b i e c OFMConv, Polscy franciszkanie - ofiary II woiny światowej. Kraków 1999 mps, s. 5-26. 
dziestu ośmiu franciszkanów zostało aresztowanych i przebywało w więzieniach w różnych miejscowościach, w różnym wymiarze czasowym ${ }^{80}$.

Odrębna grupa to franciszkanie, którzy przebywali czy to w klasztorach, czy u swoich rodzin na terenach wschodnich Rzeczpospolitej, zajętych przez Armię Czerwona. Niektórzy $\mathrm{z}$ nich zostali aresztowani, a następnie wywiezieni w gląb Związku Radzieckiego do łagrów lub na przymusowe roboty. Z tej grupy jeden franciszkanin zginał, a jedenastu innym po kilku latach udało się odzyskać wolność ${ }^{81}$.

\section{OKRES POWOJENNY}

Po wojnie, na skutek przesunięcia granic polskich na zachód, niemal cały komisariat lwowski znalazł się poza wschodnią granicą państwa. Ludność polska w ramach repatriacji opuszczala masowo te tereny udajac się do Polski centralnej lub na Ziemie Odzyskane. W wyniku repatriacji klasztory, które istniały od wieków i ostały się nawet w najcięższych czasach rozbiorów i wojen, teraz musiały być opuszczone przez franciszkanów. Jako ostatni został opuszczony 26 kwietnia 1946 r. klasztor lwowski. W wyniku wojny prowincja utraciła z 16 klasztorów w 1939 r., aż 7. Z komisariatu lwowskiego pozostały w nowych granicach Polski jedynie trzy domy: Przemyśl, Kalwaria Pacławska i Horyniec. 10 czerwca 1946 r. o. generał Hess skasował ów komisariat, a 3 pozostałe domy podporządkował komisarzowi krakowskiemu ${ }^{82}$.

Po ustaniu działań wojennych franciszkanie przystapili do usuwania szkód. Odbudowano spalony dom w Lubomierzu, postanowiono także odbudować zniszczony kościół św. Antoniego w Jaśle ${ }^{83}$. Podjęto jednocześnie starania o odzyskanie skasowanego w 1785 r. klasztoru w Nowym Sączu. Tej sprawy nie udało się jednak załatwić pomyślnie, ale zorganizowano dwa niższe seminaria: w Sanoku (1945) i Głogówku (1948)

Wobec utraty domów wschodnich podjęto starania o objęcie placówek na Ziemiach Odzyskanych. Nie było możliwe odzyskanie domów w Opolu i Bytomiu, ale w październiku 1945 r. przejęto dom w Glogówku. W tym też czasie franciszkanie objęli kilka parafii w archidiecezji wrocławskiej. W maju 1946 r. istniało na Ziemiach Odzyskanych już 15 placówek, w których pracowali franciszkanie: Głogówek, Szklarska Poręba, Krzyżatka (Kowary), Lwówek Śląski, Węgliny, Lisice, Kwietniów, Lipowa, Jawor, Słup, Roztoka, Promieniowice, Lubin, Kotla i Barkowo. Prowincja otrzymała też w 1946 r. od arcybiskupa metropo-

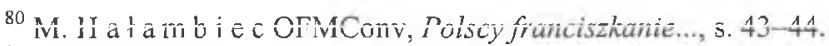

${ }^{81}$ W. J a c e w i c z SDB, J. W o ś SDB, Martyrologium polskiego duchowieństwa rzymskokatolickiego pod okupacja hitlerowska w latach 1939-1945, zeszyt V: Zakony i zgromadzenia zakonne męskie i żeńskie, Warszawa 1981.

${ }^{82}$ Katalog prowincji 1993, s. 18-19; AFK sygn. C II. Teczka Czupryk Tomasz Korneli. Życiorys.

${ }^{83}$ Z. G o g o l a OFMConv, Dzieje miejscowaści i parafii Lubomierz, Kraków 1998, s. 61-63; Z. Ś w is ta k, Franciszkanie w Jaśle, Jasło 1995, s. 49-69.

${ }^{84} \mathrm{~A} . \mathrm{K}$ u b i t OFMConv, Dzialalność duszpasterska franciszkanów konwentualnych na Ślqsku po drugiej wojnie światowej, mps, teka personalna, sygn. C. II, s. 29-44; A. K u b i t OFMConv, Wzrost prowincji franciszkanów polskich w pierwszej polowie XX wieku. Kraków 1971, mps, teka personalna, sygn. C. II, s. 77-117. 
lity krakowskiego księcia Adama Sapiehy parafię w Rychwałdzie. W ten sposób liczba domów prowincji wzrosła z 9 do 25. Poza tym franciszkanie obsługiwali 27 kościołów filialnych zachodnich parafii; w sumie pracowali w 48 kościołach $^{85}$.

Duże znaczenie dla uporządkowania życia zakonnego i usystematyzowania pracy prowincji miała pierwsza powojenna i pierwsza od podziału prowincji kapituła prowincjalna, która odbyła się w Krakowie w dniach 21-24 lipca 1947 roku. Podczas obrad dokonano wyboru prowincjała, którym został o. Wojciech Zmarz i podzielono prowincje na dwie kustodie: krakowską i przemyska. Domy na Ziemiach Odzyskanych przydzielono do kustodii krakowskiej. W międzyczasie przyjęto jeszcze domy: Święte (1946), Legnica (1947) i Wrocław - św. Karola Boromeusza $(1947)^{86}$.

W 1948 r. prowincja liczyła 177 zakonników, w tym 108 kapłanów, 45 braci i 24 kleryków. Z tej liczby 23 kapłanów i 1 brat przebywali poza granicami prowincji. W ciagu trzech następnych lat stan prowincji uległ nieznacznej zmianie. Opuszczono placówki w Lubinie i Rybotyczach. Zastapiły je Wleń i Wrocław - św. Elżbiety. W 1950 r. było 168 zakonników, w tym 101 kapłanów, 43 braci i 20 kleryków, ponadto 36 kleryków nowicjuszy i 6 kandydatów na braci. W 1951 r. przyjęto parafię w Golonogu (dom erygowano w 1959 r.). Rok 1952 byl dla prowincji mniej pomyślny, bowiem władze państwowe rozwiązały wszystkie małe seminaria zakonne i diecezjalne w kraju, również seminaria w Sanoku i Głogówku ${ }^{87}$.

W 1956 r. pod presją władz państwowych opuszczono Jawor. Wtedy też franciszkanie opuścili parafie: Słup, Pomocne, Roztokę, Lipę i Mściwojów. Po październiku 1956 r. stosunek władz państwowych do Kościoła w Polsce zmienił się na nieco bardziej pozytywny. Wyrazem tej zmiany była m.in. moźliwość uzyskania zgody państwa na otwarcie małego seminarium. O takie pozwolenie starał się w 1957 r. ówczesny prowincjał o. Anzelm Kubit. Tym razem Niższe Seminarium Franciszkanów ulokowano w klasztorze legnickim ${ }^{88}$.

W 1958 r. prowincja liczyła 21 domów, w tym 8 klasztorów uformowanych, 3 nieuformowane i 10 parafii. Liczba zakonników i kandydatów wynosiła 263 osoby, w tym 123 kapłanów, 46 braci, 67 kleryków, 3 postulantów i 27 małoseminarzystów. Kapituła prowincjalna w 1959 r. utworzyła nową kustodię - wrocławską, która obejmowała domy śląskie ${ }^{89}$.

Po drugiej wojnie światowej franciszkanie podjęli różnorakie prace. Troska o budynki kościelne, które uległy zniszczeniom w czasie wojny, towarzyszyła im ciagle. Oprócz podejmowanej pracy duszpasterskiej prowadzono duszpasterstwo chorych, kalekich, biednych. Franciszkanie objęli opieką duszpasterską szpitale, które znajdowały się w miejscowościach, w których mieli swoje klasztory. Dusz-

${ }^{85}$ Katalog Prowincji św. Antoniego i bl. Jakuba Strepy OO. Franciszkanów w Polsce z lat: 1947, 1948; S. B a r c ik OFMConv, Krakowska Prowincja Franciszkanów po drugiej wojnie światowej 1945-1990. „W nurcie franciszkańskim” $1998 \mathrm{nr} 7$, s. 297-335.

${ }^{86}$ AFK: Acta Provinciae... ab anno 1931, s. 415, 417-419, 429-436.

${ }^{87}$ Katalog Prowincji św. Antoniego i bl. Jakuba Strepy oo. Franciszkanów w Polsce z lat 1948, 1958; S. B a r c i k, Franciszkanie na Dolnym Slasku po II wojnie światowej 1945-1990, s. $150-157$.

${ }^{88}$ AFK: Acta Provinciae S. Antonii Pat. ac Beati Jacobi de Strepa in Polonia. Ab anno Dom. 1956 ad annum 1962, sygn. B-IVa-9, s. 190-193; Elenchus Fratrum Minorum S. Francisci Conventualium Provinciae S. Antoni et B. Jacobi de Strepa in Polonia 1958, s. 22.

${ }^{89}$ Elenchus... 1958, s. 38. 
pasterstwo niewidomych i głuchoniemych, czy dzieci specjalnej troski, kapelani więzienni, opieka kuracjuszy sanatoryjnych czy troska duszpasterska nad wczasowiczami to były jeszcze inne formy działalności rekolekcyjno-charytatywnej ${ }^{90}$. Z wielkim zaangażowaniem oddawali się franciszkanie pracy rekolekcyjnomisyjnej na terenie całej Polski ${ }^{9 !}$.

Stan prowincji z niewielkimi zmianami do $1970 \mathrm{r}$. i przedstawiał się następująco:

1. Kustodia krakowska: klasztory i wikariaty - Kraków, Radomsko, Lubomierz, Rychwałd, Pewel Ślemieńska (wikariat Rychwałdu), Pewel Mała (wikariat parafii Jeleśnia), Gołonóg, Biały Prądnik (wikariat parafii św. Krzyża w Krakowie). Ten ostatni wikariat opuszczono jeszcze tego samego roku.

2. Kustodia przemyska: klasztory i wikariaty - Przemyśl, Jasło, Krosno, Sanok, Kalwaria Pacławska, Horyniec, Werchrata (wikariat Horyńca) i Święte.

3. Kustodia wrocławska: klasztory i wikariaty - Wrocław - św. Karola Boromeusza, Głogówek, Legnica, Ulesie i Rzeszotary (wikariaty Legnicy), Kowary, Szklarska Poręba, Wleń, Lwówek Śląski, Kotliska (wikariat Lwówka), Zbylutów, Sobota (wikariat Zbylutowa), Pławna i Pieńsk.

Prowincja w 1970 r. liczyła 215 zakonników, w tym: 159 kapłanów, 44 braci, 21 kleryków i 8 nowicjuszy ${ }^{92}$.

\section{OKRES OSTATNIEGO TRZYDZIESTOLECIA}

Kapituła prowincjalna w 1971 r. postanowiła odstapić następujące parafie i wikariaty:

Archidiecezji krakowskiej: rektorat w Rabie Niżnej;

Archidiecezji wrocławskiej: Wleń, Pławna, Zbylutów, Sobota, Kotliska, Ulesie i Rzeszotary;

Diecezji przemyskiej: wikariat parafii Radymno w Świętem;

Archidiecezji lubaczowskiej: wikariat parafii Horyniec w Werhracie i Prusiu.

W tym też czasie przeprowadzono erekcję 6 domów na Dolnym Śląsku: Wrocław, Legnica, Lwówek Śląski, Kowary, Szklarska Poręba i Pieńsk ${ }^{93}$.

${ }^{90}$ Acta Provinciae... ab anno 1975, AFK sygn. B-IVa-12, s. 228, 607; Teka - Lubomierz w AFK sygn. D-II, kwestionariusz wizyty prowincjalnej z 1975, 1983; Teka - Raba Niżna w AFK sygn. D-II, kwestionariusz duszpasterski z 1966; Acta Provinciae... ab anno 1983, s. 272; Teka Przemyśl w AFK sygn. D II, kwestionariusze duszpasterske z $1983-1000$; Kwestionariusze duszpasterskie z lat 1964-1980 w aktach poszczególnych domów, AFK sygn. D-II Acta Provinciae... ab anno 1966, AFK sygn. B-IVa-11, s. 340, 345, 359, 404; Acta Provinciae... ab anno 1966, s. 359, 451; Acta Provinciae... ab anno 1975, AFK sygn. B-IVa-12, s. 6, 52, 5 I6.

91 Acta Provinciae... ab anno 1931, AFK sygn. B-IVa-5, s. 386, 494, 547, 551-552, Acta Provinciae... ab anno 1956, AFK sygn. B-IVa-9, s. 20, 23, 25, 28, 192.

${ }^{92}$ Elenchus Fratrum Minorum S. Francisci Conventualium provincie s. Antonii Patavini et b. Jacobi de Strepa in Polonia pro Anno Domini 1970.

${ }^{93}$ Acta Provinciae... ab anno 1966, AFK sygn. B-IVa-11, s. 57-58, 347, 349; Teka Raba Niżna, AFK sygn. D-II-221; Teka Święte, AFK sygn. D-II-257; Teka Horyniec, AFK sygn. D-11-37; „Wiadomości z Prowincji św. Antoniego i bł. Jakuba Strzemię OO. Franciszkanów w Polsce” (skrót „WzP”) 1971 nr 3 (76), s. 7. 
Dnia 17 października 1971 roku papież Paweł VI dokonał beatyfikacji ${ }^{94}$, a 10 października 1982 r. papież Jan Paweł II kanonizacji o. Maksymiliana Kolbego. Podkreślić należy, że o. Maksymilian był związany niemal całe życie zakonne z Prowincją św. Antoniego i bł. Jakuba Strzemię $e^{95}$. W 1972 r. wikariuszem zakonu został o. prof. Joachim Bar, co było wielkim wyróżnieniem prowincji ${ }^{96}$.

Po 1970 r. zaistniała możliwość wyjazdu na misje zagraniczne, która znalazła pozytywny oddźwięk wśród franciszkanów. W 1972 r. wyjechali do Zambii o. Jan Kalembkiewicz, o. Marcin Zagórski, o. Franciszek Stopkowicz, o. Albert Cużyt i o. Franciszek Kowol ${ }^{97}$. W 1974 r. utworzono samodzielny wikariat w Głowience k. Krosna, gdzie później zbudowano kościół i dom mieszkalny. W 1975 r. prowincja przejęla od diecezji kieleckiej obiekty franciszkańskie w Nowym Korczynie w tym klasztor zlikwidowany jeszcze przez władze carskie w 1864 r. Razem z klasztorem przejęto tamtejszą parafię z drugim kościołem ${ }^{98}$.

W 1976 r. obchodzono jubileusz 750-lecia śmierci założyciela Zakonu, św. Franciszka z Asyżu. Franciszkanie krakowscy odpowiedzieli pozytywnie na propozycję arcybiskupa Luisa Rodrigueza, ordynariusza diecezji Santa Cruz w Boliwii, skierowaną do generała zakonu o. Vitale Bommarco, która dotyczyła objęcia placówki misyjnej w Boliwii. Chcieli w ten sposób równiez uhonorować franciszkański jubileusz. Z różnych powodów społeczno-politycznych prowincja nie prowadziła w ówczesnym czasie żadnej działalności misyjnej, poza pozostałymi w Japonii braćmi z dawnej misji św. Maksymiliana. Dlatego propozycja ponownego wkroczenia na drogę pracy misyjnej, poza granicami Polski, spotkała się z pozytywnym i przychylnym odzewem ze strony przełożonego prowincji o. Albina Dudka i wspólbraci, którzy deklarowali gotowość do podjęcia pracy na terytorium państwa boliwijskiego. Decyzja ta spotkała się również z akceptacja Kościoła w Polsce. Podobnie jak krakowska prowincja franciszkanów, tak i cały Kościół w Polsce zostal przez władze komunistyczne pozbawiony najbardziej wiarygodnego elementu swej żywotności i duchowej siły, którą jest misyjna obecność pośród ludności potrzebującej ewangelizacji. Zadowolenie $z$ podjętej inicjatywy wyrazili przedstawiciele polskiego Episkopatu: prymas Stefan kard. Wyszyński i metropolita krakowski Karol kard. Wojtyła ${ }^{99}$. Jako pierwsi podjęli tam pracę: o. Szymon Chapiński, o. Rufin Orecki i o. Jan Koszewski. W rok później dołączył do nich o. Peregryn Ziobro, następnie o. Stanisław Olbrycht i inni misjonarze. Misja w Boliwii ma aktualnie 6 placówek: w Montero (dom założony w 1976 r., erygowany 27 VII 1983 r.), Cochabamba (1979 r., 27 VII 1983 r.), Sucre (1985 r., 1 I 1986 r.), Cochabamba - Chacacollo (seminarium, 21 IX 1988 r.), Santa Cruz

${ }^{94}$ D. Synowiec, Beatyfikacja, „WzP” 1972 nr I(78), s. 49-56.

95 Męczennik mitości. Kanonizacja bl. Maksymiliana Kolbego, „L'Osservatore Romano” (wyd. polskie) 1982 nr 9, s. 1, 3-4.

${ }^{96}$ J. B a r, ,WzP” 1972 nr 5(82), s. 6-7.

$97 \mathrm{~J}$. K a l e m b k i e w i c z OFMConv, Wspomnienia z Afryki z pracy misyjnej w Zambii w latach 1972-1979, Kraków 2003.

98 Teka Glowienka, AFK sygn. D-II, Akta z 1984 r.; Teka Nowy Korczyn, AFK sygn. D-II, Akta z lat 1975-1992.

99 AFK List metropolity krakowskiego ks. Karola Wojtyły do przełożonego i ojców misjonarzy $z$ dn. 25 VI $1976 \mathrm{r}$. 
(1987 r., 4 VII 1992 r.) i Libertad - Juirgarzama (1993 r.) ${ }^{100}$. W 1986 r. erygowano kustodię boliwijska, co dało misji nowe uprawnienia ${ }^{101}$.

Zarząd generalny zakonu zaproponował również Prowincji utworzenie nowej misji w Peru. Zgodnie z uchwała Rady Prowincjalnej z dn. 30 czerwca 1988 ro$\mathrm{ku}^{102}$ po przyjęciu przez Prowincję misji w Peru, dwaj kandydaci rozpoczęli przygotowania do wyjazdu. O. Zbigniew Strzałkowski i o. Jarosław Wysoczański udali się do Peru 30 listopada 1988 roku $^{103}$. Episkopat peruwiański bardzo życzliwie zareagowal na założenie nowej misji franciszkanów, praca bowiem przebiegała pomyślnie. Współpraca z siostrami Esclavas del Sagrado de Jesús pracującymi w Pariacoto pozwoliła na szybszą adaptację misjonarzy w Andach. Misja napawała wielką nadzieją i radościa, gdyż rozwijała się bardzo dobrze. Tak było do 9 sierpnia 1991 r., kiedy to dwaj franciszkanie - o. Zbigniew Strzałkowski i o. Michał Tomaszek zostali zamordowani przez terrorystów ugrupowania „Sendero Luminoso". Terroryści dokonali zabójstwa ok. godziny $21^{00}$ na miejscu starego kościoła przy drodze z Pariacoto do Cochabamby. Rozstrzelani zostali na leżąco strzałami w tył głowy i w plecy. Na plecach o. Zbigniewa mordercy zostawili tekturową tabliczkę ze znakiem sierpa i młota oraz napisem "Tak giną lizusy imperializmu”. Podpisany był wykonawca wyroku ${ }^{104}$. Pomimo trudności misja nadal funkcjonuje i rozwija się. Konferencja Plenarna Episkopatu Peru w dn. 24 stycznia 1995 r. pozwoliła na rozpoczęcie procesu beatyfikacyjnego o. Zbigniewa i o. Michała oraz wyraziła zgodę, aby prosić Stolicę Apostolską o skrócenie czasu z pięciu do czterech lat od śmierci misjonarzy. Proces został przeprowadzony, a dokumentacja przekazana do Kongregacji do Spraw Świętych dnia 11 października $2002 \mathrm{r}^{105}$

Trzecim krajem, w którym Prowincja podjęła się misji, był Paragwaj. Duszpasterstwo misyjne polegało przede wszystkim na wydawaniu Rycerza Niepokalanej - „Tupasy Ne'e” w języku guarani, które zainicjował o. Rufin Orecki. W 1992 r. Kapituła Prowincjalna przyjęła dzieło o. Rufina i uznała je za misje Prowincji. „Tupasy Ne'e" wydawany jest nadal jako miesięcznik w nakładzie ok. 15 tys. egzemplarzy ${ }^{106}$.

Po rozdzieleniu się Czech i Slowacji franciszkanie czescy na kapitule w Opawie w dniu 12 lutego 1993 r. przekazali odpowiedzialność za Słowację generałowi Zakonu Lanfranco Serriniemu, który zwrócił się do Prowincji św. Antoniego $\mathrm{i}$ bł. Jakuba Strzemię w tej sprawie i została zawarta umowa między pro-

100 J. B a j o w s k i, Boliwia franciszkańska. Historia i duch misyjny. Kraków 1999, s. 85-112.

101 AFK Dokumentacja Kapituly Prowincjalnej. Kraków 16-21 VI 1986 r; „WzP” 1986 nr 3(159) ร. 7 .

102 Archiwum Kurii Prowincjalnej Franciszkanów w Krakowie (AKPK): Korespondencja generała zakonu o. Lanfranco Serriniego do prowincjała o. Feliksa Stasicy z 14 IV 1988 r.; Misja w Peru, „WzP” 1988 nr 3(169), s. 4.

${ }^{103}$ Wyjazd dwóch misjonarzy do Peru, ,WzP” $1988 \mathrm{nr} 4(170)$, s. 19.

$104 \mathrm{~J}$. W y s o c z ańs ki OFMConv, $O$ wschodzie rodzi się nowe życie. „Bratni Zew” 1992 nr 5, s. 26-29; Z. G o g o l a OFMConv, Dzialalność misyjna Braci Mniejszych Konwentualnych w Peru, Kraków 2003, s. 419-478.

${ }^{105}$ Relacja o. Carlosa Gomeza Comesañy z oficjalnego otwarcia dokumentacji procesu beatyfikacyjnego naszych męczenników z Peru, „WzP” 2002 nr 3(225), s. 22.

106 Uchwaty Kapituly Prowincjalnej. Chęciny 18-22 V; 2-4 VI 1992, „WzP” $1992 \mathrm{nr}$ 2(186), s. 5, 47-48. 
wincją czeską a wyżej wspomnianą w dniu 15 czerwca 1993 r. ${ }^{107} \mathrm{Na}$ wniosek prowincjała Czech Minister Kultu Republiki Słowackiej w dniu 3 marca 1994 r. uznał osobowość prawną Zakonu Braci Mniejszych Konwentualnych w tym kraju. Prowincja pracowała usilnie nad wskrzeszeniem zakonu w Słowacji. Efektem było utworzenie Kustodii Prowincjalnej pw. Matki Bożej Niepokalanej w 2002 r. ${ }^{108}$

Od 1991 r. Prowincja podjęła pracę w Uzbekistanie i uzyskała od władz uzbeckich dawny kościół - ruinę w Taszkiencie, który po odrestaurowaniu służy pracy duszpasterskiej. W 1997 r. misja na terenie Uzbekistanu została ogloszona formalnie „missio sui iuris”, a jej przełożonym został o. Krzysztof Kukułka. Oprócz Taszkientu misja franciszkańska w Uzbekistanie obejmowała Samarkandę, Ferganę i Bucharę ${ }^{109}$. Szczególną misją jest Kałmucja przejęta w 1995 r. ${ }^{110}$ Decyzja o otwarciu nowej misji w Ugandzie zapadła na kapitule prowincjalnej w 2000 r. Misja w Kakooge znajduje się w młodej diecezji Kasana-Luweero zlokalizowanej w bliskim sąsiedztwie stolicy Kampala ${ }^{11}$.

W ostatnim trzydziestoleciu XX wieku Prowincja powiększyła się o nowe klasztory i parafie. Zaliczyć należy do nich miejscowości: Głowienka - parafia 1975 r., nowy klasztor 1984 r. ${ }^{112}$, Lubomierz - kaplica na Rzekach, OświęcimHarmęże - nowy klasztor, kościół parafialny i Centrum Św. Maksymiliana Kolbego 1990 r. $^{113}$, Rychwałd - dom pielgrzyma ${ }^{114}$, Kalwaria Pacławska - Nowicjat, dom pielgrzyma 1995 r., Horyniec Zdrój - klasztor i poszerzony drugi kościół, Jasło - klasztor poszerzony o nowy budynek, Krosno - klasztor poszerzony o nowy budynek, Kraków - odzyskanie budynku klasztoru zajmowanego przez ludzi świeckich i generalny remont, Kraków - nowy klasztor św. Antoniego - budynek Kurii Prowincjalnej 1992 r. ${ }^{15}$, Chęciny - odzyskanie dawnego klasztoru i kościoła $^{116}$, Nowy Korczyn - odzyskanie obiektów pofranciszkańskich, następnie po dłuższym użytkowaniu przekazanie na rzecz diecezji kieleckiej, Lwówek Śląski odzyskanie kościoła franciszkańskiego i klasztoru, Dąbrowa Górnicza-Gołonóg zbudowanie nowego klasztoru ${ }^{11}$.

Lublin - założenie nowego klasztoru - domu dla studentów z Prowincji, Glogówek - przywrócenie do użytkowania klasztoru i stworzenie domu formacyjnego, Zielona Góra - przyjęcie nowej parafii - budowa klasztoru i kościoła.

${ }^{107}$ Archiwum Kurii Prowincjalnej Franciszkanów w Krakowie (AKPK). Teka Słowacja.

${ }^{108}$ AKPK Uchwały Nadzwyczajnej Kapituły Prowincjalnej. Zuberec 23-26 IX 2002 r.

109 AKPK Z. G o g o l a OFMConv, Sprawozdanie o stanie prowincji św. Antoniego $i$ bl. Jakuba Strzemie w Polsce na Kapitułe Prowincjalnq w Kalwarii Pactawskiej w maju 1996 r, mps, s. 88-89; Uchwala Kapituly Prowincjalnej z 2000 r. o misji sui iuris w Uzbekistanie, „WzP” $1996 \mathrm{nr} 2(201)$, s. 10-11; „WzP" $2000 \mathrm{nr} 2(217)$, s. 5-7.

110 AKPK Z. G o g o l a OFMConv, Sprawozdanie..., s. 91.

111 AKPK Uchwała Kapituły Prowincjalnej o otwarciu misji w Ugandzie.

112 Acta Provinciae... ab anno 1966, AFK sygn. B-IVa-11, s. 456, 571; Acta Provinciae... ab anno 1983, s. 278; Katalog z Prowincji 1993, s. 22.

113 Wiadomości z Oświęcinia-Harmęż, „WzP” 1991 nr 1(179), s. 30.

114 Z. G o g o la OFMConv, Sanktuarium Matki Bożej Ziemi Zywieckiej w Rychwaldzie. Żywiec 1999, s. 224.

${ }^{115}$ Klasztor erygowany 25.12 .1992 r., „WzP” $1992 \mathrm{nr} 3(187)$, s. 20.

${ }^{116}$ Po 174 latach zakon odzyskuje klasztor w Chęcinach, ,WzP” 1991 nr 2(180), s. 54-58

${ }^{117}$ Sprawozdanie prowincjała ze stanu i działalności Prowincji św. Antoniego i bl. Jakuba Strzemię za okres 1989-1992, „WzP” 1992 nr 2(186), s. 39-45; Sprawozdanie prowincjała z $1996 \mathrm{r}$. 
Prowincja $w$ ramach pomocy Zakonowi podejmowała pracę na terenie innych prowincji w Europie. Przyjęto klasztory i parafie: w Niemczech w Rattingen 1986 r., Glessen 1990 r. Oggersheim i Neustadt, we Włoszech w Fossanovie 1991 r. Przejęto kościół św. Antoniego we Lwowie, nabyto posiadłości na własność Prowincji w Zakopanem, Piwnicznej i Krakowie ${ }^{118}$.

Prowincja podjęła wiele znacznych dzieł - między innymi: Franciszkańskie Spotkania Młodych w Kalwarii Pacławskiej, Franciszkańskie Pismo Młodych zniesione na kapitule prowincjalnej w 1996 r., Wydawnictwo „Bratni Zew”, Fundacja św. Franciszka z Asyżu, Festiwal Piosenki Religijnej, Ruch Ekologiczny św. Franciszka z Asyżu - REFA. Ważną działalnością w Prowincji jest praca duszpasterska. W 1996 r. na 22 klasztory, jakie prowincja posiadała w kraju, w 17 prowadzono parafię. Na 15 domów poza Polską było 11 parafii. Posługa duszpasterska ześrodkowywała się na tradycyjnym apostolstwie. Zakres oddziaływania prowincji był rozległy. Oprócz Polski franciszkanie pracowali w 14 krajach świata. Prowadzona była także działalność duszpasterska specjalna poprzez: Ruch Światło-Życie, domy rekolekcyjne, rekolekcje i misje ludowe, duszpasterstwo sanktuariów: Sanktuarium Podwyższenia Krzyża Świętego i Matki Bożej w Kalwarii Pacławskiej, Sanktuarium Matki Bożej w Rychwałdzie, Sanktuarium Matki Bożej Loretańskiej w Głogówku, Sanktuarium Matki Bożej Bolesnej w Krakowie, Sanktuarium Matki Bożej Łaskawej Patronki i Opiekunki Małżeństwa i Rodzin we Wrocławiu, Sanktuarium Matki Bożej Bolesnej w Radomsku, Sanktuarium św. Antoniego w Jaśle, Dąbrowie Górniczej-Gołonogu ${ }^{119}$.

Na polu naukowym można także odnotować znaczne osiagnięcia. Kilkunastu franciszkanów pracuje na uczelniach PAT, KUL oraz Gregorianum i Seraphicum w Rzymie. Wyższe Seminarium Duchowne OO. Franciszkanów od ponad stu lat kształci i przygotowuje młodych franciszkanów do podejmowania posługi duszpasterskiej. Umowa z PAT gwarantuje zachowanie programu, dzięki któremu studenci szóstego roku otrzymują magisterium ${ }^{120}$. Zaniechano prowadzenia Niższego Seminarium w Legnicy na rzecz Katolickiego Liceum Ogólnokształcącego.

Podsumowując dzieje franciszkanów Prowincji św. Antoniego i bł. Jakuba Strzemię, należy podkreślić ich duży wkład w życie Kościoła powszechnego i zakonu w Polsce i na świecie. Mimo przeciwności burzliwych dziejów Polski franciszkanie działają do czasu obecnego. Trzeba zauważyć szczególny fenomen klasztoru krakowskiego, który od przybycia pierwszych braci św. Franciszka w 1237 r. $^{121}$ bez przerwy funkcjonuje nie tylko jako obiekt zabytkowy, ale jako wspólnota życia franciszkańskiego uczestnicząca w ewangelizacji ludu i szerzeniu misji. Jest „matką” wszystkich polskich klasztorów franciszkańskich. Obiekt jako zabytek zerowej klasy zawiera w sobie pamięć historii Polski Krakowa oraz blisko

118 AFK Sprawozdanie prowincjała na Kapitułę Prowincjalną w Kalwarii Pacławskiej 1996 r., mps, s. 63, 89, 109

119 AKPK Sprawozdanie prowincjała na Kapitułe Prowincjalną w Kalwarii Pacławskiej w $1996 \mathrm{r}$.

120 S. B arcik, Franciszkańskie Studium w Krakowie. Stulecie reerekcji 1892-1992, „WzP” 1992 nr 3(187), s. 28-40.

${ }^{121}$ Sz. S kibińs k i, Program ideowy i funkcje kościoła Franciszkanów w Krakowie, [w:] Sztuka i ideologia XIII wieku. Wrocław 1974, s. 333-341. 
osiemsetletnią historię polskich franciszkanów ${ }^{122}$. Jest głęboko związany $z$ dawnymi i wspólczesnymi dziejami miasta i archidiecezji krakowskiej. Przez całe osiem stuleci Franciszkanie otaczali swój kościół i klasztor troską, dzięki czemu do naszych czasów, mimo kataklizmów dziejowych, dotrwało wiele dawnych, jeszcze gotyckich zabytków. Dzięki otwartości władz klasztornych, angażujących także własne środki materialne w prace remontowe towarzyszące pracom konserwatorskim, możliwe było przywrócenie dawnej świetności zarówno kościołowi, jak i klasztorowi oraz przeprowadzenie badań naukowych, w wyniku których dokonano odkrycia m.in. zatynkowanych, wysokiej klasy artystycznej, gotyckich polichromii.

Podjęta próba przedstawienia rysu dziejów franciszkanów w Polsce sięga swymi korzeniami XIII wieku. Zainicjowany przez o. Jana z Pian del Carpini, prowincjała Niemiec, rozwój zakonu na terenach słowiańskich miał różne kształty organizacyjne i przechodził różne koleje losu. Franciszkanie przybyli do Polski w 1234 r. Od początku byli świadkami i uczestnikami utrwalania chrześcijaństwa w Polsce, promotorami sztuki i rozwoju społecznego. Ta dialektyka między ciągłością i unowocześnieniem ich obecności w polskim kontekście socjo-kulturowym i eklezjalnym wymagała ciągłej rewizji zarówno stylu przeżywania własnej tożsamości, jak również kryteriów, dzięki którym franciszkanie stali się mocnym bodźcem ewangelizowania młodego kościoła polskiego i zakładania nowych struktur kościelnych na kresach Rzeczpospolitej.

Od tego czasu wielokrotnie zmieniały się granice Polski, organizacja zakonu, granice prowincji. Rosnące znaczenie franciszkanów powodowało podejmowanie coraz to nowych inicjatyw w zakresie duszpasterskim, misyjnym. Zakładali kalwarie na ziemiach polskich i litewskich, wprowadzili w życie zwyczaje szopki bożonarodzeniowej, nabożeństwa pokutne, rozbudzili kult Matki Bożej Niepokalanej.

Kult pasyjny stanowi jedną $z$ cech duchowości św. Franciszka i był bardzo żywy w zakonie franciszkanów. Szczególnym przedmiotem tego kultu w bazylice krakowskiej franciszkanów jest wizerunek Matki Bożej zwanej Smętną Dobrodziejka. Rozwój kultu Matki Bożej Bolesnej, współcierpiącej z umęczonym Jezusem, stał u podstaw założenia bractwa Męki Pańskiej w 1595 r., które prowadziło szeroką działalność do rozbiorów Polski. Wyrazem kultu Matki Bożej Bolesnej było założenie Bractwa pod koniec XIX w. Jednak kult cudownego wizerunku Matki Bożej Bolesnej był niezwykle żywy i obejmował dużą część Polski.

Od drugiej wojny światowej Prowincja św. Antoniego i bł. Jakuba Strzemię rozwija się nieustannie. Znakiem zewnętrznym jest stały wzrost liczby franciszkanów. W 1996 r. Prowincja liczyła 423 profesów wieczystych i czasowych, w tym 238 kapłanów, 36 braci zakonnych, 28 kleryków o ślubach solemnych. W Prowincji św. Antoniego i bł. Jakuba Strzemię klasztory franciszkańskie znajdują się w 24 miejscach, a za granicą w 17. Średnia wieku nieco powyżej 45 lat ${ }^{123}$.

122 Prezydent Miasta Krakowa Jacek Majchrowski na wniosek Bractwa Mecenatu Kultury przyznał 25 VI 2004 r. tytuł Mecenasa Kultury Krakowa Roku 2003 w kategorii ochrony zabytków klasztorowi oo. Franciszkanów w Krakowie. Dokument w archiwum klasztoru Franciszkanów w Krakowie.

${ }^{123}$ AKPK Sprawozdanie prowincjała na Kapitułę Prowincjalną w Oświęcimiu - Harmężach w $2000 \mathrm{r}$. 
Rozwój cechuje także Prowincję Matki Bożej Niepokalanej z siedzibą w Warszawie oraz wyłonioną z niej w $1985 \mathrm{r}$. nową prowincję św. Maksymiliana Marii Kolbego z siedzibą w Gdańsku.

Prowincja krakowska wkroczyła w XXI wiek ze stanem liczbowym zakonników podobnym do stanu z okresu swego bujnego rozkwitu, tzn. z czasów Polski przedrozbiorowej.

\section{History of Franciscan Friars of St. Anthony and Blessed Jakub Strzemię Province in Poland Summary}

An attempt to show the history of the Franciscan Friars in Poland originated in the $13^{\text {th }}$ century. The development of the order in Slavonic territories, initiated by a provincial of Germany Jan of Pian del Carpini, was going through different organizational stages and experienced its ups and downs. Franciscan Friars arrived in Poland in 1234. From the start they witnessed and participated in consolidating Christianity in Poland; they were promoters of art and social development. Dialectic between continuity and up-dating their presence in the Polish socio-cultural and ecclesiastical context required constant verification of the way of experiencing their own identity as well as the criteria, owing to which they became a strong impulse in the evangelisation of the young Polish church and in the establishing new church structures in borderland areas.

Since that time the borders have been changed many times and so has the organization of the order and the borders of the province. The growing importance of Franciscan Friars resulted in taking up new pastoral and missionary initiatives. Franciscan Friars established Calvaries in Poland and Lithuania, introduced the tradition of Christmas crèches and penitential services. Last but not least, they evoked the cult of the Immaculate Virgin Mary.

Since World War II St Anthony and the Blessed Jakub Strzemie Province has been developing steadily. A growing number of Franciscan Friars testifies to this development. In 1996 the Province had 423 professed monks, including 238 priests, 36 brothers, 28 clerics who have taken solemn vows. In St. Anthony and the Blessed Jakub Strzemię Province Franciscan monasteries are located in 24 places and 17 are abroad. The average age is slightly over 45 years.

The Province of the Immaculate Virgin Mary, which is based in Warsaw, has also noted a steady growth and so has a new province that developed from it - - St. Maximilian Maria Kolbe Province with the seat in Gdańsk.

The Cracow Province entered the $21^{\text {st }}$ century with the number of monks similar to that from its most thriving period, that is the times preceding the partition of Poland. 